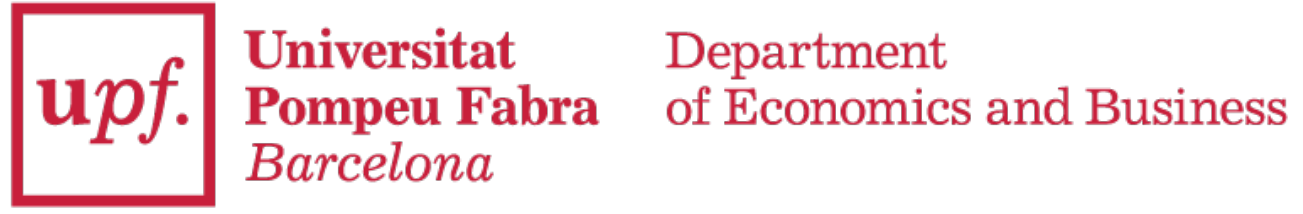

Economics Working Paper Series

Working Paper No. 1602

\title{
Democratic tipping points
}

Antonio Ciccone

March 2018 


\title{
Democratic Tipping Points
}

\author{
Antonio Ciccone*
}

March 2018

\begin{abstract}
I examine whether transitory events can tip the scales against authoritarian regimes and lead to persistent democratization. I think of situations where this is a possibility as democratic tipping points. The transitory events I focus on are rainfall shocks in the most agricultural countries in the world. I show that while these shocks only affect agricultural output contemporaneously, they have persistent effects on political institutions. Authoritarian regimes experiencing negative rainfall shocks are more likely to be democratic three, five, and ten years later.
\end{abstract}

*Mannheim University, ICREA-UPF, and Barcelona GSE; antonio.ciccone@gmail.com. I thank Adilzhan Ismailov and Ricardo Maertens for excellent research assistance. I also thank seminar participants at the Universities of Frankfurt, Heidelberg, Lausanne, Naples, Oxford, and Southampton for useful comments. 


\section{Introduction}

I examine whether transitory events can tip the scales against authoritarian regimes and lead to persistent democratization. I think of situations where this is a possibility as democratic tipping points. The transitory events I focus on are rainfall shocks in the most agricultural countries in the world. I show that while these shocks only affect agricultural output contemporaneously, they have persistent effects on political institutions. Authoritarian regimes experiencing negative rainfall shocks are more likely to be democratic three, five, and ten years later. This holds using different indicators of authoritarian versus democratic regimes.

An influential theory of political transitions with democratic tipping points is Acemoglu and Robinson (2001). In their theory, the initially disenfranchised poor majority can contest the political power of a rich elite. As the opportunity cost of contesting power is lower following transitory negative economic shocks, transitory negative shocks can lead to democratization. Democratization may be followed by autocratic reversal or it may be permanent, depending on the constellation of several factors - income inequality and the opportunity cost of coups for example. The constellations of factors where transitory negative economic shock would lead to permanent democratization can be thought of as democratic tipping points.

The most agricultural countries in the world are a logical place to look for democratic tipping points. In the 1960 s and 1970 s, towards the beginning of the time period I examine, almost all of them were ruled by authoritarian regimes. Half a century later, around half of these countries had become democratic. The factors enabling a political transition from an authoritarian to a democratic political system must therefore have been in place in these countries. Moreover, the great importance of agriculture and the lack of irrigation in these countries make rainfall shocks an important source of economic shocks. It is therefore natural to ask whether transitory rainfall shocks could have lead to persistent democratization by tipping the scales against the authoritarian regimes that were ruling these countries.

I start my empirical analysis by examining the effect of rainfall shocks on agricultural output. I find a comparatively strong and entirely contemporaneous effect of rainfall shocks on agricultural output in countries with agricultural GDP shares in the top quintile of the distribution. The median year-on-year drop in rainfall causes a drop in agricultural output of 
around $1 \%$ in these countries.

I then go on to show that transitory rainfall shocks have persistent effects on democratic institutions in these countries, whether I use dichotomous measures of democratic institutions that classify regimes into either autocratic or democratic, or multi-valued indices of the quality of democratic institutions. The two dichotomous political regime classifications I use are the classification of Geddes, Wright, and Frantz (2014) and the classification of Przeworski, Alvarez, Cheibub, and Limongi (2000) as updated by Cheibub, Gandhi, and Vreeland (2010) and Bjornskov and Rode (2017). I find that the median year-on-year negative rainfall shock makes countries ruled by authoritarian regimes around one to two percentage points more likely to be democratic after one to three years. After ten years, these countries are two to three percentage points more likely to be democratic. The finding that negative rainfall shocks trigger persistent democratization is confirmed when I use the Polity Project combined polity score to measure democratic change and also when I use the Freedom House index of political rights. Taken together, my empirical results indicate that exogenous, transitory events can tip the scales against authoritarian regimes and lead to persistent democratization.

My work fits into the literature on the economic determinants of democratic change. Some of the more recent contributions are Przeworski and Limongi (1997), Barro (1999), Przeworski, Alvarez, Cheibub, and Limongi (2000), Acemoglu, Johnson, Robinson, and Yared (2008), Burke and Leigh (2010), Bruckner and Ciccone (2011), Aidt and Franck (2015), and Caselli and Tesei (2016). My contribution is to investigate the existence of democratic tipping points by examining whether transitory shocks can lead to persistent democratization. Within the literature, I am closest to Acemoglu, Johnson, Robinson, and Yared (2008) and to Bruckner and Ciccone (2011). Acemoglu, Johnson, Robinson, and Yared and I have in common that we both examine the effect of income changes on democratic change over the short run as well as the longer run. The main difference is that I examine the effect of transitory income shocks, while they analyze the consequences of more persistent changes in income. Bruckner and Ciccone and I have in common that we both examine the consequences of rainfall shocks. The main difference is that they solely examine the short-run, year-on-year change in democratic institutions, while my interest is in longer-run, persistent changes.

Lipset (1959) appears to be first in observing that democratic change is often sparked by 
economic recessions. Haggard and Kaufman (1995) and Acemoglu and Robinson (2001, 2006) add empirical content and Acemoglu and Robinson provide a theoretical framework to study the link between economic factors and democratization. Their theory brings out a key point: economic recessions can lead to persistent democratic change even if the recession itself is short-lived. My contribution to the literature is to investigate this hypothesis empirically.

The remainder of this paper is structured as follows. Sections 2 and 3 present the data and the empirical specifications. Section 4 discusses the results. Section 5 concludes.

\section{Data}

\subsection{Agricultural Output and Rainfall Data}

The agricultural output data I use is the real crops production index of the United Nation's Food and Agricultural Organization (FAOSTAT, 2016). The index is available annually since around 1960 for some 160 countries. I use it to examine the effect of rainfall on agricultural output in countries grouped by their average share of agriculture in GDP over the sample period. The agricultural GDP shares come from the World Development Indicators (2016).

The rainfall data comes from the United States Government's National Oceanic and Atmospheric Administration. This data is available globally on a 0.5 degree latitude times 0.5 degree longitude grid. The temperature data comes from the United States Government's Center for Environmental Prediction and is available globally on a 2 degree latitude times 2 degree longitude grid at the equator. I aggregate the rainfall and temperature data to the country-year level (to match the country-year agricultural output and democratization data).

For the time period since 1980, I also use alternative measures of country-year rainfall and temperature. These are obtained by combining the disaggregated rainfall and temperature data mentioned above with new, high-resolution satellite data on growing seasons for most countries in the world between the years 1982 and 2012 (Garonna, de Jong, and Schaepman, 2016). My alternative measures of country-year rainfall and temperature, capture rainfall and temperature over agricultural land during the growing season and are constructed following the agricultural economics literature (e.g. Schlenker and Lobell, 2010; Lobell, Schlenker, and 
Costa-Roberts, 2011; I follow Maertens, 2016, who uses this approach for Sub-Saharan African countries with satellite data available for these countries only). I first use the Garonna, de Jong, and Schaepman (2016) data to obtain the average start and end dates of the growing season in each weather cell. I then calculate the total amount of rainfall and the average temperature during the growing season in each cell. Finally I weight each cell by the share of agricultural land in it using the data in Nachtergaele and Petri (2013) for the year 2000 and aggregate these weighted cells to the country level.

\section{$2.2 \quad$ Measuring Democracy}

I use two dichotomous measures of democratic institutions that classify regimes into either autocratic or democratic, and two multi-valued measures of the quality of democratic institutions. The two dichotomous measures are the autocratic/democratic regime classification of Geddes, Wright, and Frantz (2014) and of Przeworski, Alvarez, Cheibub, and Limongi (2000) as updated by Cheibub, Gandhi, and Vreeland (2010) and Bjornskov and Rode (2017). I drop years where according to Geddes, Wright, and Frantz, the country is not independent, occupied by a foreign nation, or there is no government controlling most of the territory. The two multi-valued indices measuring the quality of democratic institutions I use are the Polity Project's combined polity score and Freedom House's index of political rights (Marshall and Jaggers, 2005; Freedom House, 2007). I drop so-called interregnum years where according to the Polity Project there is no government controlling most of the territory. Former colonies are only included since independence.

It is useful to keep in mind that the different measures of democratic improvements I employ differ in definitions and technical implementation. As a result, they indicate a somewhat different timing for democratic improvements over short periods and sometimes even longer periods, even though they point in the same direction in the long run.

Countries with a high share of agriculture in GDP over the time period I study were overwhelmingly autocratic at the beginning of the period (for most countries the first observation is between 1960 and the early 1970s). For example, according to the classification of Geddes et al. or Przeworski et al., almost all countries with agricultural GDP shares in the top quintile were autocratic at the beginning of my time period. The average combined polity score in this 
group of countries in 1970 was -6 (with -10 the most autocratic and 10 the most democratic value on the scale). By 2013, the end of the time period I study, around half of these countries were classified as democratic and their average polity score was 2 .

\section{Empirical Framework}

The estimating equation for the effect of rainfall on real agricultural output follows the agricultural economic literature, see Schlenker and Lobell (2010), Lobell, Schlenker, and Costa-Roberts (2011), and Maertens (2016) for example. The literature finds the within-country effect of rainfall on agricultural output to be quadratic and inverted-U-shaped. I therefore model the effect of rainfall on agricultural output as

$$
\begin{aligned}
& \text { RealAgriculturalOutputIndex }_{c, t}=\text { Controls }_{c, t} \\
& +\left(a_{0} R_{c, t}+b_{0} R_{c, t}^{2}\right)+\left(a_{1} R_{c, t-1}+b_{1} R_{c, t-1}^{2}\right)+\left(a_{2} R_{c, t-2}+b_{2} R_{c, t-2}^{2}\right)
\end{aligned}
$$

where the three terms $a R+b R^{2}$ capture the (quadratic) within-country effect of rainfall at different lags and Controls $_{c, t}$ always include (i) country fixed effects; (ii) year fixed effects; (iii) country-specific linear time trends, and (iv) linear-quadratic terms for temperature that match the lag structure of the rainfall variable. The quadratic specification for the effect of rainfall implies that there can be too much rain as far as agricultural productivity is concerned. The method of estimation is least squares with robust standard errors clustered at the country level. ${ }^{1}$

The estimating equation for the effect of rainfall on democratization outcomes between years t-1 and T mirrors the estimating equation for agricultural output

$$
\begin{aligned}
& \text { Democratization }_{c, t-1}^{T}=\text { Controls }_{c, t} \\
& +\left(\alpha_{0} R_{c, t}+\beta_{0} R_{c, t}^{2}\right)+\left(\alpha_{1} R_{c, t-1}+\beta_{1} R_{c, t-1}^{2}\right)+\left(\alpha_{2} R_{c, t-2}+\beta_{2} R_{c, t-2}^{2}\right)
\end{aligned}
$$

\footnotetext{
${ }^{1}$ I also estimate the equation using GDP per capita from the Penn World Tables on the left-hand side but never find any significant effects. A likely explanation is the noise in PWT GDP per capita, see Johnson, Papageorgiu, and Subramanian (2013).
} 
where the three terms $\alpha R+\beta R^{2}$ capture the effect of rainfall at different lags and Controls $_{c, t}$ always include (i) country fixed effects; (ii) year fixed effects; (iii) country-specific linear time trends, and (iv) linear-quadratic terms for temperature that match the lag structure of the rainfall variable. ${ }^{2}$ The method of estimation is least squares with robust standard errors clustered at the country level.

Democratization between $\mathrm{t}-1$ and $\mathrm{T}$ in (2) is measured in two main ways. The first measure is a democratization indicator based on dichotomous political regime classifications. The democratization indicator takes the value of 1 if the country is an autocracy in year t-1 but a democracy in year T. The democratization indicator takes the value of 0 if the country is an autocracy in year t-1 and an autocracy in year T. The second measure of democratization is based on multi-valued indices measuring the quality of democratic institutions. In this case, democratization between $\mathrm{t}-1$ and $\mathrm{T}$ is measured as the absolute change between $\mathrm{t}-1$ and $\mathrm{T}$ in the index if this change is towards more democratic institutions.

If the effect of rainfall on agricultural output in (1) is inverted-U-shaped and the effect of rainfall on democratization is through agricultural output, the effect of rainfall on democratization in (2) should be U-shaped. Moreover, the vertex of the inverted-U-shaped effect of rainfall on agricultural output should be at a similar level of rainfall as the vertex of the U-shaped effect of rainfall on democratization.

\section{Empirical Results}

\subsection{Effects on Agricultural Output}

Table 1 summarizes the results on the effect of rainfall on agricultural output using equation (1). The different columns look at results for different groups of countries.

Column (1) considers countries whose average share of agricultural output in GDP over the 1960-2013 period is in the top quintile of the distribution. The group consists of 32 countries with data for around 50 years. The contemporaneous effect of rainfall on agricultural output is statistically significant and inverted-U-shaped, and the lagged effects are statistically insignifi-

\footnotetext{
${ }^{2} \mathrm{My}$ empirical specifications actually include one additional rainfall lag but it is usually statistically insignificant and not reported.
} 
cant. To get a sense of the strength of the contemporaneous effect, it is useful to calculate the fall in agricultural output caused by the median year-on-year drop in rainfall starting at the median level of rainfall (which I refer to as the median negative rainfall shock). This effect is around $-1 \%$. As the average share of agriculture in countries in the top quintile of the distribution is around 40\%, the implied effect on GDP of the median negative rainfall shock is around $-0.4 \%{ }^{3}$ The lagged effects of rainfall are not only statistically insignificant but also small quantitatively. The conclusion of column (1) is that rainfall has a significant but transitory effect on agricultural output in the most agricultural countries in the world.

Column (2) considers countries whose average share of agricultural output in GDP is outside of the top quintile of the distribution (the complement of the group of countries in column (1)). Now both the contemporaneous and the lagged effects of rainfall on agricultural output are statistically insignificant. The implied contemporaneous effect of the median negative rainfall shock on agricultural output is basically zero.

Columns (3) and (4) consider countries whose average share of agricultural output in GDP is in the top quarter and the top tercile of the distribution respectively. The contemporaneous effect of rainfall on agricultural output is statistically significant and inverted-U-shaped, and the lagged effects are statistically insignificant. The implied contemporaneous effect of the median negative rainfall shock on agricultural output is around $-0.3 \%$ in countries in the top quarter of the distribution and around $-0.4 \%$ in countries in the top tercile. This is substantially smaller than in countries with agricultural GDP shares in the top quintile of the distribution. Given the average GDP shares of agriculture in the top quarter and the top tercile of the distribution, the implied effect of the median negative rainfall shock on GDP is around $-0.1 \%$ to $-0.15 \%$. This is approximately one third of the implied GDP effect in countries with agricultural GDP shares in the top quintile of the distribution.

One explanation for the drop off in the effect of rainfall on agricultural output as one moves outside the group of countries with agricultural GDP shares in the top quintile, is irrigation. There is very little irrigation in countries in the top quintile of the distribution of agricultural GDP shares. According to the World Development Indicators (2016), the median

\footnotetext{
${ }^{3}$ I do not find any significant effects when I reestimate the equation with (log) GDP per capita from the PWT on the left-hand side of the regression (see footnote 1). This is true for all groups of countries in Table 1.
} 
share of irrigated agricultural land in these countries over the 2000-2010 period was around $0.5 \%$. Outside of the group of countries in the top quintile, the share of irrigated agricultural land is much higher. For example, the median share of irrigated agricultural land in countries with agricultural GDP shares in the top tercile but not the top quintile of the distribution, was around 10\%. Another explanation is that as one moves outside of the group of countries with agricultural GDP shares in the top quintile, more and more of the measured rainfall is not over agricultural land and hence will not have an effect on agricultural output.

Column (4) considers all countries with agricultural output data. The contemporaneous quadratic effect of rainfall on agricultural output is statistically significant and inverted-Ushaped, and the lagged effects are statistically insignificant. The implied contemporaneous effect of the median negative rainfall shock on agricultural output is small, around $-0.1 \%$, and the implied effect on GDP is even smaller, around $0.01 \%$.

\subsection{Effects on Democratic Change: From Short to Longer Term}

Tables 2, 3, and 4 summarize the short- and longer-run effects of transitory rainfall shocks on different measures of democratic change in countries with agricultural GDP shares in the top quintile of the distribution. I start with indicators of democratization based on the dichotomous political regime classifications of Przeworski, Alvarez, Cheibub, and Limongi (2000) and of Geddes, Wright, and Frantz (2014), and then turn to measures of democratic change based on the Polity Project combined polity score and the Freedom House political rights index. ${ }^{4}$

Measuring democratization following Przeworski et al. The left panel of Table 2 summarizes the results when the measure of democratization in (2) is based on the dichotomous political regime classification of Przeworski, Alvarez, Cheibub, and Limongi (2000) as updated by Cheibub, Gandhi, and Vreeland (2010) and Bjornskov and Rode (2017) - which I refer to as Przeworski et al. in short. In this case, democratization is an indicator which is only defined if the country is an autocracy in year t-1. The democratization indicator between years t-1 and $\mathrm{T}$ takes the value of 1 if the country is a democracy in year $\mathrm{T}$. If the country is an autocracy in year $\mathrm{T}$, the democratization indicator takes the value of 0 . The table summarizes the effect of

\footnotetext{
${ }^{4}$ The measures of democracy are not always available for all countries.
} 
rainfall shocks on this democratization indicator for different $\mathrm{T}$. The results indicate the effect of rainfall on the probability that an autocracy in year t-1 is a democracy in year t (one year later); in year $\mathrm{t}+2$ (three years later); in year $\mathrm{t}+4$ (five years later); and in year $\mathrm{t}+9$ (ten years later).

The main empirical finding is that the effect of rainfall in year $t$ on the Przeworski et al. democratization indicator is statistically significant and U-shaped for democratization between year $\mathrm{t}-1$ and year $\mathrm{t}$ (one year later); year $\mathrm{t}+2$ (three years later); year $\mathrm{t}+4$ (four years later); and year t+9 (ten years later). ${ }^{5}$ The strength of the effect of rainfall shocks on the probability of democratization is illustrated in Figure 1 for the median negative rainfall shock in year t. The median negative rainfall shock is defined as the median year-on-year drop in rainfall starting at the median level of rainfall. The figure contains the point estimates (the dots) and the corresponding $90 \%$ confidence intervals. It can be seen that the median year-t negative rainfall shock increases the probability of democratization between years t-1 and t by around 1.5 percentage points. The $90 \%$ confidence interval ranges from 0.5 percentage points to 2.5 percentage points. By year $t+2$, the median year-t negative rainfall shock increases the probability of democratization by 2.3 percentage points. The $90 \%$ confidence interval goes from 0.5 percentage points to 4.1 percentage points. By year $t+4$, the increase in the probability of democratization is above 3 percentage points. And by year $t+9$, the increase in the probability of democratization is around 2.5 percentage points, with a $90 \%$ confidence interval from 0.8 percentage points to 4.2 percentage points. Hence, transitory negative rainfall shocks lead to persistent democratization according to the Przeworski et al. political regime classification.

Figure 3 compares the effect of year-t rainfall on agricultural output (solid line, measured on the left scale) calculated using Table 1 column (1), with the effect of year-t rainfall on the probability of a Przeworski et al. democratization between years t-1 and t (dotted line, measured on

\footnotetext{
${ }^{5}$ Appendix Tables 1 and 2 contain separate results for, respectively, Sub-Saharan African countries and countries outside of Sub-Saharan Africa. It can be seen that rainfall affects short- and longer-run democratization as defined by Przeworski et al. in both groups of countries (despite the smaller sample size). Appendix Tables 3 and 4 contain results for the time period since 1980 for all countries with agricultural GDP shares in the top quintile since 1980. This (shorter) time period allows me to compare the effects of rainfall with the effect of rainfall over agricultural land during the growing season (for the latter the necessary data is only available since 1982; see the data section for details). It can be seen that rainfall as well as rainfall over agricultural land during the growing season affect short- and longer-run democratization since 1980 (despite the smaller sample size).
} 
the right scale) calculated using Table 2 column (1). The effect of rainfall on agricultural output is inverted-U-shaped. The effect of rainfall on the probability of democratization is U-shaped. The vertex of the inverted-U-shaped effect on agricultural output is at a similar level of rainfall as the vertex of the U-shaped effect on democratization, as it should be if the effect of rainfall on democratization arises through agricultural output. A formal hypothesis test cannot reject that the two vertices are reached at the same level of rainfall at any standard confidence level. ${ }^{6}$

Measuring democratization following Geddes et al. The right panel in Table 2 summarizes the results when the democratization indicator in (2) is based on the dichotomous political regime classifications of Geddes, Wright, and Frantz (2014). The results again indicate a statistically significant, U-shaped effect of rainfall on the probability of democratization over different time periods. ${ }^{7}$ The timing of the rainfall effect is somewhat different than for the Przeworski et al. classification in the left panel. In particular, for the shorter one- and threeyear periods, it is rainfall in year t-1 that is statistically significant. Differences in timing are not particularly surprising as the two classifications use different regime definitions and measurement criteria. A specific difference between the Geddes et al. and the Przeworski et al. regime classifications that probably matters most for the particular difference in the timing of the rainfall effect is that Geddes et al. do not follow "the convention" (their own words) in coding the start date of democratic regimes. If a democratic regime becomes established in year $t$, the convention is to code December 31 of that year as the start date. Geddes et al. use January 1 of the subsequent year instead (Przeworski et al. use the convention for the start date of democratic regimes). To see how the convention regarding democratic regime start dates affects the results imagine that a negative year-t rainfall shock causes a democratization in year t. With the December 31 convention, the democratization is recorded in year $\mathrm{t}$ and

\footnotetext{
${ }^{6}$ The test that the two vertices are reached at the same level of rainfall is based on a SURE regression combining the estimating equations in (1) and (2).

${ }^{7}$ Appendix Tables 1 and 2 contain separate results for, respectively, Sub-Saharan African countries and countries outside of Sub-Saharan Africa. It can be seen that rainfall affects short- and longer-run democratization as defined by Geddes et al. in both groups of countries (despite the smaller sample size). Appendix Tables 3 and 4 contain results for the time period since 1980 for all countries with agricultural GDP shares in the top quintile since 1980. This (shorter) time period allows me to compare the effects of rainfall with the effect of rainfall over agricultural land during the growing season (for the latter the necessary data is only available since 1982; see the data section for details). It can be seen that rainfall as well as rainfall over agricultural land during the growing season affect short- and longer-run democratization since 1980 (despite the smaller sample size).
} 
researchers would observe that negative year-t rainfall shocks result in democratization in year t. With the January 1 convention, the democratization is recorded in year $\mathrm{t}+1$ and researchers would observe that negative year-t rainfall shocks result in democratization in year t+1 (or put differently, that year-t democratizations are related to negative rainfall shocks in year t-1).

Because of the unconventional rule for the start dates of democratic regimes used by Geddes, Wright, and Frantz, I illustrate the strength of the effect of the median negative rainfall shock in year $\mathrm{t}$ on the probability of democratization in Figure 3 in two different ways. My first approach uses the results in Table 2, column (5) and therefore relies on the original Geddes et al. data. The corresponding point estimates are the red dots in Figure 3. It can be seen that the median year-t negative rainfall shock increases the probability that an autocracy in year $\mathrm{t}-1$ is a democracy in year $\mathrm{t}$ by around 0.8 percentage points. The $90 \%$ confidence interval ranges from -0.2 percentage points to 1.8 percentage points. The probability that the autocratic country is a democracy in year $\mathrm{t}+4$ or in year $\mathrm{t}+9$ is around 2.5 percentage points. The $90 \%$ confidence interval goes from around 0.6 percentage points to around 4.3 percentage points. Hence, transitory negative rainfall shocks lead to persistent democratization according to the political regime classification of Geddes, Wright, and Frantz. My second approach recodes the start dates of regimes in the Geddes et al. data according to the convention, reestimates the specification in Table 2, column (5) using this recoded data, and then uses these results to illustrate the strength of the effect of the median negative rainfall shock in year $t$ on the probability of democratization between years t-1 and t. The corresponding point estimates are the blue squares. In this case, the median year-t negative rainfall shock increases the probability of democratization between years $\mathrm{t}-1$ and $\mathrm{t}$ by around 1.5 percentage points. The $90 \%$ confidence interval ranges from 0.2 percentage points to 2.8 percentage points. The probability that the autocratic country is a democracy in year $t+4$ or in year $t+9$ is around 2 percentage points. The $90 \%$ confidence interval goes from 0.1 percentage points to 4 percentage points.

The effect of rainfall on the probability of a Geddes et al. democratization between years t-1 and $t$ can be compared with the effect of rainfall on agricultural output as well as the effect of rainfall on a Przeworski et al. democratization in Figure 2. Because of the unconventional rule for start dates of regimes used by Geddes at al., the figure shows the probability of a Geddes et al. democratization in function of rainfall in $t-1$. The effect of rainfall on the probability of a 
Geddes et al. democratization can be seen to be U-shaped and similar to the effect of rainfall on the probability of a Przeworski et al. democratization (dashed and dotted lines, measured on the right scale). The vertex of the U-shaped effect of rainfall on the probability of a Geddes et al. democratization is at a similar level of rainfall as the vertex of the inverted-U-shaped effect of rainfall on agricultural output, as it should be if the effect of rainfall on democratization arises through agricultural output. A formal hypothesis test cannot reject that the two vertices are reached at the same level of rainfall at any standard confidence level.

Measuring democratic improvement following the Polity Project The left panel in Table 3 summarizes the results when democratic change in (2) is measured by the improvement in the Polity Project combined polity score. The polity score ranges from -10 to 10, with higher values indicating more democratic institutions.

As I am interested in improvements in democratic institutions in autocracies, I use the positive change between years $\mathrm{t}-1$ and $\mathrm{T}$ in the combined polity score in autocracies in $\mathrm{t}-1$ as the measure of democratic improvement. Negative changes, which correspond to democratic setbacks, are dropped from the analysis (the results including negative changes are similar, see Appendix Table 5). I follow the convention that countries with a polity score smaller or equal -1 are autocracies. By focusing the analysis on democratic improvements in autocracies, I am staying as close as possible to the analysis of democratization in Table 2.

Table 3 shows the results for the effect of rainfall on the democratic improvements between year $\mathrm{t}-1$ and year $\mathrm{t}$ (one year later); year $\mathrm{t}+2$ (three years later); year $\mathrm{t}+4$ (four years later); and year $t+9$ (ten years later) in a country that is an autocracy in year $t-1$. The effect of year- $t$ rainfall is statistically significant and U-shaped over all time periods.

The strength of the effect of rainfall shocks on democratic improvements is illustrated in Figure 4 for the median negative rainfall shock. The figure illustrates the point estimates (the dots) and $90 \%$ confidence intervals. The effect of the median year-t negative rainfall shock on the improvement in the polity score between years $\mathrm{t}-1$ and $\mathrm{t}$ is around 0.12 polity points. The $90 \%$ confidence interval ranges from 0.01 to 0.23 polity points. The improvement in the polity score between years $t-1$ and $t+2$ (three years later) is around 0.31 points. The $90 \%$ confidence interval goes from 0.11 to 0.51 polity points. By year $t+4$ and year $t+9$ (five and 
ten years later), the improvement in the polity score increases to around $0.35-0.4$ points. The 90\% confidence interval of the effect on democratic improvement by year $t+9$ ranges from 0.12 to 0.58 polity points. Hence, transitory negative rainfall shocks lead to persistent democratic improvements according to the Polity Project.

Figure 5 compares the effect of year-t rainfall on agricultural output (solid line, measured on the left scale) calculated using Table 1 column (1), with the effect of year-t rainfall on the democratic improvement between years t-1 and t according to the polity score (dotted line, measured on the right scale) calculated using Table 3 column (1). The effect of rainfall on democratic improvement can be seen to be U-shaped. Moreover, the vertex of the effect of rainfall on democratic improvement is at a similar level of rainfall as the vertex of the effect of rainfall on agricultural output. A formal hypothesis test cannot reject that the vertices are reached at the same level of rainfall at any standard confidence level.

The right panel in Table 3 contains the results for the effect of rainfall on a democratization indicator based on the dichotomized combined polity score. I follow the convention in classifying countries with a polity score smaller or equal -1 as autocracies and all other countries as democracies. The results indicate statistically significant, U-shaped effects of rainfall on the probability of democratization over different time periods. However, the timing of the rainfall effect on the dichotomized polity score is different than the timing for the improvement in the polity score in the left panel of Table 3 and the timing for the democratization indicators in Table 2. This is not particularly surprising as the different measures of democratization are based on different definitions. For example, the results for the improvement in the polity score in the left panel of Table 3 indicate the effect of rainfall on improvements in the polity score no matter which level is reached. On the other hand, the results for the dichomotomized polity score in the right panel of Table 3 indicate the effect of rainfall on improvements in the polity score that are large enough for the score to cross the threshold level where the country starts being classified as a democracy. The timing difference between the results for the dichomotomized polity score in the right panel of Table 3 and the dichotomous democratization indicators in Table 2, probably reflects that the dichotomous regime classifications in Table 2 have a narrower focus on free and fair elections.

The strength of the effect of rainfall shocks on the probability of a polity democratization 
is illustrated in Figure 6 for the median year-t negative rainfall shock. The median year$\mathrm{t}$ negative rainfall shock increases the probability of democratization between $\mathrm{t}-1$ and $\mathrm{t}$ by around 0.8 percentage points. The $90 \%$ confidence interval ranges from -0.5 percentage points to 2.1 percentage points. By year $\mathrm{t}+2$, the median year-t negative rainfall shock increases the probability of democratization by around 3 percentage points. The $90 \%$ confidence interval goes from around 1 percentage points to around 5 percentage points. By year $\mathrm{t}+9$, the increase in the probability of democratization is around 2.4 percentage points. The $90 \%$ confidence interval ranges from 0.4 percentage points to 4.4 percentage points. $^{8}$

Measuring political rights following Freedom House Table 4 summarizes the results when democratic improvement in (2) is measured by the improvement in the Freedom House index of political rights. The index ranges from 1 to 7 , with higher values indicating less political rights. Put differently, an improvement in political rights corresponds to a drop in the political rights index. To make results more comparable with those obtained using the Polity Project combined polity score, where higher values indicate more democratic institutions, I use the negative of the Freedom House political rights index as the basis of my empirical work. This leaves the range of the index unchanged but ensures that positive changes over time correspond to improvements in political rights. Just like in the case of the combined polity score, I focus on improvements in political rights and drop years where political rights deteriorate (the results including negative changes are similar, see Appendix Table 5). ${ }^{9}$

Table 4 shows the results for the effect of rainfall on the improvements in political rights between year t-1 and year t; year t+2 (three years later); year $t+4$ (five years later); and year $\mathrm{t}+9$ (ten years later). The effect of rainfall in year $\mathrm{t}$ on improvements in political rights is statistically significant and U-shaped over all time periods.

The strength of the effect of negative rainfall shocks on improvements in political rights is illustrated in Figure 7 for the median year-t negative rainfall shock. The figure illustrates

\footnotetext{
${ }^{8}$ This effect is statistically significant although the corresponding linear and quadratic effects in Table 3 column (8) are not, because the standard error for the effect of the median negative rainfall shock on the probability of democratization by year $t+9$ also depends on the covariance of the estimates for the linear and quadratic rainfall effects.

${ }^{9} \mathrm{I}$ am not looking at results in autocracies only as the Freedom House political rights index is not used for classifying countries into democratic and autocratic regimes.
} 
the point estimates (the dots) and $90 \%$ confidence intervals. The effect of the median year-t negative rainfall shock is an improvement in political rights of around 0.03 points in year t. The 90\% confidence interval ranges from -0.02 to 0.08 points. By year $t+2$, the increase in political rights is around 0.08 points and the $90 \%$ confidence interval goes from 0.02 to 0.14 points. By year $t+4$ and year $t+9$ (five and ten years later), the improvement in political rights rises to around 0.15 points. The $90 \%$ confidence interval ranges from 0.06 to 0.24 points. Hence, transitory negative rainfall shocks lead to persistent improvements in political rights according to Freedom House.

\section{Conclusion}

The idea that persistent differences in political institutions may be driven by entirely transitory events is intriguing. I examine it empirically by analyzing the effects of transitory rainfall shocks on political institutions in the most agricultural countries in the world. I focus on the most agricultural countries in the world because many of them did make a transition from authoritarian regimes to democracies over the last half century, and because the importance of agriculture and the lack of irrigation make rainfall shocks a significant source of economic shocks in these countries. My empirical work first establishes that transitory rainfall shocks affect agricultural output in these countries and that the effect is transitory. I then go on to show that rainfall shocks have persistent effects on political institutions. In particular, negative rainfall shocks make it significantly more likely that autocracies are (more) democratic three, five, and ten years later. This leads me to conclude that transitory events can tip the scales against authoritarian regimes and lead to persistent democratization. 


\section{References}

ACEMOGLU, D. and J.A. ROBINSON (2001). A Theory of Political Transitions. The American Economic Review, 91, 938-963.

ACEMOGLU, D. and J.A. ROBINSON (2006). Economic Origins of Dictatorship and Democracy. New York, Cambridge University Press.

ACEMOGLU, D., S. JOHNSON, J.A. ROBINSON, and P. YARED (2008). Income and Democracy. The American Economic Review, 98, 808-842.

BARRO, R. (1999). Determinants of Democracy. Journal of Political Economy, 107, S158S183.

AIDT, T.S. and R. FRANCK (2015). Democratization under the Threat of Revolution: Evidence from the Great Reform Act of 1832. Econometrica, 83, 505-547.

BJORNSKOV, C. and M. RODE (2017). Regime Types and Regime Changes: A New Dataset. Available at http://www.christianbjoernskov.com.

BRUCKNER, M. and A. CICCONE (2011). Rainfall and the Democratic Window Opportunity. Econometrica, 79, 923-947.

BURKE, P. and A. LEIGH (2010). Do Output Contractions Trigger Democratic Change? American Economic Journal: Macroeconomics, 2, 124-157.

CASELLI, F. and A. TESEI (2016). Resource Windfalls, Political Regimes, and Political Stability. Review of Economics and Statistics, 98, 573-590.

CHEIBUB, J., J. GANDHI and J.R. VREELAND (2010). Democracy and Dictatorship Revisited. Public Choice, 143, 67-101.

FAOSTAT (2016). Online Database, United Nations.

FREEDOM HOUSE (2007). Freedom in the World Country Ratings, 1972-2007. Washington, DC, Freedom House.

GARONNA, I., R. de JONG, and M. SCHAEPMAN (2016). Variability and Evolution of Global Land Surface Phenology over the Last Three Decades (1982-2012). Global Change Biology, 22, 1456-1468. 
GEDDES, B., J. WRIGHT, and E. FRANTZ (2014). A New Data Set: Autocratic Breakdown and Regime Transition. Perspectives on Politics, 12, 313-331.

HAGGARD, S. and R. KAUFMAN (1995). The Political Economy of Democratic Transitions. Princeton, Princeton University Press.

JOHnSON, S., C. PAPAGEORGIU, and A. SUBRAMANIAN (2013). Is Newer Better? Penn World Table Revisions and their Impact on Growth Estimates. The Journal of Monetary Economics, 60, 255-274.

LIPSET, S. (1959). Some Social Prerequisites for Democracy: Economic Development and Political Legitimacy. American Political Science Review, 53, 69-105.

LOBELL, D. B., W. SCHLENKER, and J. COSTA-ROBERTS (2011). Climate Trends and Global Crop Production since 1980. Science, 333, 616-620.

MAERTENS, R. (2016). Adverse Rainfall Shocks and Civil War: Myth or Reality? Households in Conflict Network (HiCN) Working Paper 212.

MARSHALL, M. and K. JAGGERS (2005). Polity IV Project: Dataset Users' Manual. Center for Global Policy, George Mason University.

NACHTERGAELE, F. and M. PETRI (2013). Mapping Land Use Systems at Global and Regional Scales for Land Degradation Assessment Analysis. FAO, United Nations.

PRZEWORSKI, A. and F. LIMONGI (1997). Modernization: Theories and Facts. World Politics, 49, 155-183.

PRZEWORSKI, A., M. ALVAREZ, J. CHEIBUB, and F. LIMONGI (2000). Democracy and Development: Political Institutions and the Well-Being of the World, 1950-1990. Cambridge: Cambridge University Press.

SCHLENKER, W. and D. B. LOBELL (2010). Robust Negative Impacts of Climate Change on African Agriculture. Environmental Research Letters, 5, 4010.

WORLD DEVELOPMENT INDICATORS (2016). Online Database, World Bank. 


\section{TABLE 1. Rainfall Shocks and Agricultural Output since 1960: Effect by Share of Agriculture in Gross Domestic Product}

\begin{tabular}{|c|c|c|c|c|c|}
\hline & $\begin{array}{c}\text { Top Quintile } \\
\text { Agricultural } \\
\text { Countries }\end{array}$ & $\begin{array}{l}\text { All Countries } \\
\text { Except Top } \\
\text { Quintile } \\
\text { Agricultural } \\
\text { Countries } \\
\text { (2) }\end{array}$ & $\begin{array}{c}\text { Top Quarter } \\
\text { Agricultural } \\
\text { Countries }\end{array}$ & $\begin{array}{c}\text { Top Tercile } \\
\text { Agricultural } \\
\text { Countries }\end{array}$ & $\begin{array}{c}\begin{array}{c}\text { All } \\
\text { Countries }\end{array} \\
(5)\end{array}$ \\
\hline Rainfall $\mathrm{t}$ & $\begin{array}{c}2.23^{* * *} \\
(0.63)\end{array}$ & $\begin{array}{c}0.59 \\
(0.59)\end{array}$ & $\begin{array}{l}1.07 * * \\
(0.54)\end{array}$ & $\begin{array}{l}1.17^{* *} \\
(0.46)\end{array}$ & $\begin{array}{l}0.84^{*} \\
(0.46)\end{array}$ \\
\hline $\begin{array}{l}\text { Quadratic } \\
\text { Rainfall } t\end{array}$ & $\begin{array}{c}-0.059 * * * \\
(0.013)\end{array}$ & $\begin{array}{c}-0.03 \\
(0.024)\end{array}$ & $\begin{array}{c}-0.033^{* * *} \\
(0.01)\end{array}$ & $\begin{array}{c}-0.034^{* * *} \\
(0.01)\end{array}$ & $\begin{array}{c}-0.032^{* *} \\
(0.016)\end{array}$ \\
\hline Rainfall t-1 & $\begin{array}{c}0.12 \\
(0.63)\end{array}$ & $\begin{array}{c}0.28 \\
(0.63)\end{array}$ & $\begin{array}{l}-0.31 \\
(0.52)\end{array}$ & $\begin{array}{l}-0.046 \\
(0.46)\end{array}$ & $\begin{array}{c}0.35 \\
(0.49)\end{array}$ \\
\hline $\begin{array}{l}\text { Quadratic } \\
\text { Rainfall t-1 }\end{array}$ & $\begin{array}{c}-0.01 \\
(0.014)\end{array}$ & $\begin{array}{c}-0.02 \\
(0.024)\end{array}$ & $\begin{array}{l}0.0002 \\
(0.01)\end{array}$ & $\begin{array}{l}-0.003 \\
(0.01)\end{array}$ & $\begin{array}{c}-0.02 \\
(0.017)\end{array}$ \\
\hline Rainfall t-2 & $\begin{array}{c}0.25 \\
(0.62)\end{array}$ & $\begin{array}{l}-0.46 \\
(0.67)\end{array}$ & $\begin{array}{l}-0.27 \\
(0.51)\end{array}$ & $\begin{array}{l}-0.16 \\
(0.45)\end{array}$ & $\begin{array}{l}-0.16 \\
(0.52)\end{array}$ \\
\hline $\begin{array}{l}\text { Quadratic } \\
\text { Rainfall t-2 }\end{array}$ & $\begin{array}{l}-0.002 \\
(0.014)\end{array}$ & $\begin{array}{l}-0.002 \\
(0.025)\end{array}$ & $\begin{array}{c}0.007 \\
(0.012)\end{array}$ & $\begin{array}{c}0.005 \\
(0.011)\end{array}$ & $\begin{array}{l}-0.006 \\
(0.018)\end{array}$ \\
\hline $\begin{array}{l}\text { Linear \& } \\
\text { Quadratic } \\
\text { Temperature } \\
\text { in Different } \\
\text { Years }\end{array}$ & $Y$ & $Y$ & $Y$ & $Y$ & Y \\
\hline $\begin{array}{l}\text { Country Fixed } \\
\text { Effects }\end{array}$ & Y & Y & $Y$ & Y & Y \\
\hline $\begin{array}{l}\text { Year Fixed } \\
\text { Effects }\end{array}$ & Y & Y & $Y$ & $Y$ & Y \\
\hline $\begin{array}{l}\text { Country } \\
\text { Specific Linear } \\
\text { Time Trends }\end{array}$ & $Y$ & Y & $Y$ & Y & Y \\
\hline Countries & 32 & 129 & 40 & 53 & 164 \\
\hline Observations & 1,514 & 5,684 & 1,891 & 2,434 & 7,220 \\
\hline R Squared & 0.066 & 0.017 & 0.032 & 0.024 & 0.022 \\
\hline
\end{tabular}

Note: The left-hand side variable is an index of real agricultural output. Countries are assigned to subsamples by the average share of agricultural in GDP over the sample period. The table reports robust standard errors clustered at the country level. ${ }^{*}$ denotes significance at the $10 \%$ level; $* *$ significance at the $5 \%$ level; and ${ }^{* * *}$ significance at the $1 \%$ level. 


\section{TABLE 2. Rainfall Shocks and Democratization since 1960: From Short to Longer Term}

\begin{tabular}{|c|c|c|c|c|c|c|c|c|}
\hline & \multicolumn{4}{|c|}{ Przeworski et al. Democratization } & \multicolumn{4}{|c|}{ Geddes et al. Democratization } \\
\hline & \multicolumn{4}{|c|}{ Przeworski et al. Democratization between $\mathrm{t}-1$ and } & \multicolumn{4}{|c|}{ Geddes et al. Democratization between $\mathrm{t}-1$ and } \\
\hline & $\begin{array}{l}\mathrm{t}(1- \\
\text { Year })\end{array}$ & $\begin{array}{l}\mathrm{t}+2(3- \\
\text { Year) }\end{array}$ & $\begin{array}{c}t+4(5- \\
\text { Year) }\end{array}$ & $\begin{array}{c}\text { t+9 (10- } \\
\text { Year) }\end{array}$ & t (1-Year) & $\begin{array}{l}\mathrm{t}+2(3- \\
\text { Year) }\end{array}$ & $\begin{array}{l}\mathrm{t}+4(5- \\
\text { Year) }\end{array}$ & $\mathrm{t}+9$ (10-Year) \\
\hline & (1) & (2) & (3) & (4) & (5) & (6) & (7) & (8) \\
\hline Rainfall t & $\begin{array}{c}-0.032^{* *} \\
(0.014)\end{array}$ & $\begin{array}{c}-0.042^{* *} \\
(0.02)\end{array}$ & $\begin{array}{c}-0.058^{* * *} \\
(0.021)\end{array}$ & $\begin{array}{c}-0.046^{* *} \\
(0.02)\end{array}$ & $\begin{array}{l}-0.013 \\
(0.01)\end{array}$ & $\begin{array}{l}-0.011 \\
(0.016)\end{array}$ & $\begin{array}{c}-0.035^{*} \\
(0.019)\end{array}$ & $\begin{array}{c}-0.047^{* *} \\
(0.02)\end{array}$ \\
\hline $\begin{array}{l}\text { Quadratic } \\
\text { Rainfall t }\end{array}$ & $\begin{array}{l}0.0008^{*} \\
(0.0005)\end{array}$ & $\begin{array}{l}0.0009 * \\
(0.0005)\end{array}$ & $\begin{array}{c}0.0012^{* *} \\
(0.0005)\end{array}$ & $\begin{array}{c}0.001^{*} \\
(0.0006)\end{array}$ & $\begin{array}{c}0.0003 \\
(0.0003)\end{array}$ & $\begin{array}{c}0.0001 \\
(0.0004)\end{array}$ & $\begin{array}{c}0.0005 \\
(0.0004)\end{array}$ & $\begin{array}{c}0.001^{*} \\
(0.0005)\end{array}$ \\
\hline Rainfall t-1 & $\begin{array}{c}0.011 \\
(0.0122)\end{array}$ & $\begin{array}{l}-0.018 \\
(0.018)\end{array}$ & $\begin{array}{l}-0.024 \\
(0.017)\end{array}$ & $\begin{array}{c}-0.048^{* *} \\
(0.019)\end{array}$ & $\begin{array}{c}-0.034^{* *} \\
(0.015)\end{array}$ & $\begin{array}{l}-0.033^{*} \\
(0.019)\end{array}$ & $\begin{array}{c}-0.046^{* *} \\
(0.018)\end{array}$ & $\begin{array}{l}-0.035^{*} \\
(0.018)\end{array}$ \\
\hline $\begin{array}{l}\text { Quadratic } \\
\text { Rainfall t-1 }\end{array}$ & $\begin{array}{c}-0.0003 \\
(0.0003)\end{array}$ & $\begin{array}{c}0.0002 \\
(0.0004)\end{array}$ & $\begin{array}{c}0.0003 \\
(0.0005)\end{array}$ & $\begin{array}{l}0.001^{* *} \\
(0.0005)\end{array}$ & $\begin{array}{c}0.0009 * * \\
(0.0004)\end{array}$ & $\begin{array}{l}0.0009 * \\
(0.0005)\end{array}$ & $\begin{array}{c}0.0011^{* *} \\
(0.0005)\end{array}$ & $\begin{array}{c}0.0009^{* *} \\
(0.0004)\end{array}$ \\
\hline Rainfall t-2 & $\begin{array}{l}-0.022^{*} \\
(0.013)\end{array}$ & $\begin{array}{l}-0.034^{*} \\
(0.017)\end{array}$ & $\begin{array}{l}-0.017 \\
(0.016)\end{array}$ & $\begin{array}{l}-0.031 \\
(0.019)\end{array}$ & $\begin{array}{c}0.014 \\
(0.012)\end{array}$ & $\begin{array}{c}-0.016 \\
(0.016)\end{array}$ & $\begin{array}{l}-0.026 \\
(0.015)\end{array}$ & $\begin{array}{c}-0.038^{* *} \\
(0.019)\end{array}$ \\
\hline $\begin{array}{l}\text { Quadratic } \\
\text { Rainfall t-2 }\end{array}$ & $\begin{array}{c}0.0003 \\
(0.0003)\end{array}$ & $\begin{array}{c}0.0006 \\
(0.0004)\end{array}$ & $\begin{array}{c}0.0003 \\
(0.0004)\end{array}$ & $\begin{array}{c}0.0005 \\
(0.0005)\end{array}$ & $\begin{array}{l}-0.0004 \\
(0.0003)\end{array}$ & $\begin{array}{c}0.0002 \\
(0.0004)\end{array}$ & $\begin{array}{c}0.0005 \\
(0.0004)\end{array}$ & $\begin{array}{c}0.0007 \\
(0.0005)\end{array}$ \\
\hline $\begin{array}{l}\text { Linear \& } \\
\text { Quadratic } \\
\text { Temperature in } \\
\text { Different Years }\end{array}$ & $\mathrm{Y}$ & $\mathrm{Y}$ & $\mathrm{Y}$ & $\mathrm{Y}$ & $\mathrm{Y}$ & $\mathrm{Y}$ & $\mathrm{Y}$ & $\mathrm{Y}$ \\
\hline $\begin{array}{l}\text { Country Fixed } \\
\text { Effects }\end{array}$ & $\mathrm{Y}$ & $\mathrm{Y}$ & $\mathrm{Y}$ & $\mathrm{Y}$ & $\mathrm{Y}$ & $\mathrm{Y}$ & $\mathrm{Y}$ & $\mathrm{Y}$ \\
\hline Year Fixed Effects & Y & $\mathrm{Y}$ & Y & Y & Y & Y & Y & Y \\
\hline $\begin{array}{l}\text { Country Specific } \\
\text { Linear Time } \\
\text { Trends }\end{array}$ & $\mathrm{Y}$ & $\mathrm{Y}$ & $\mathrm{Y}$ & $\mathrm{Y}$ & $\mathrm{Y}$ & $\mathrm{Y}$ & Y & Y \\
\hline Countries & 26 & 26 & 26 & 26 & 26 & 26 & 26 & 26 \\
\hline Observations & 1,051 & 1,013 & 978 & 892 & 1,048 & 1,011 & 977 & 889 \\
\hline R Squared & 0.033 & 0.033 & 0.034 & 0.022 & 0.023 & 0.03 & 0.052 & 0.039 \\
\hline
\end{tabular}

Note: The left-hand-side variable in columns (1) and (5) is an indicator variable that takes the value of 1 if a country that is an autocracy at $t-1$ is a democracy at $t$ and the value of 0 otherwise. The left-hand-side variable in columns (2) and (6) is an indicator variable that takes the value of 1 if a country that is an autocracy at $t-1$ is a democracy at $t+2$ and the value of 0 otherwise. The left-hand-side variable in columns (3) and (7) is an indicator variable that takes the value of 1 if a country that is an autocracy at t-1 is a democracy at $\mathrm{t}+4$ and the value of 0 otherwise. The left-hand-side variable in columns (4) and (8) is an indicator variable that takes the value of 1 if a country that is an autocracy at $t-1$ is a democracy at $t+9$ and the value of 0 otherwise. The classification of democratic and autocratic regimes in columns (1)-(4) is based on Bjornskov and Rode (2017) who extend the dataset of Cheibub, Gandhi, and Vreeland (2010) and Przeworski, Alvarez, Cheibub, and Limongi (2000). The classification of democratic and autocratic regimes in columns (5)-(8) is based on Geddes, Wright, and Frantz (2014). The included countries are all countries in Table 1 column (1) (countries with an average share of agricultural in GDP over the sample period in the top quintile of the distribution) with democratization data. The table reports robust standard errors clustered at the country level. ${ }^{*}$ denotes significance at the $10 \%$ level; ${ }^{* *}$ significance at the $5 \%$ level; and ${ }^{* * *}$ significance at the $1 \%$ level. 


\section{TABLE 3. Rainfall Shocks and Polity Project Democratic Change since 1960: From Short to Longer Term}

Polity Project Democratic Improvement

\section{Polity Improvement between $\mathrm{t}-1$ and}

$\frac{\mathrm{t}(1-\text { Year) }}{(1)} \frac{\begin{array}{c}\mathrm{t}+2(3- \\ \text { Year) }\end{array}}{(2)} \frac{\begin{array}{c}t+4(5- \\ \text { Year })\end{array}}{(3)} \frac{\begin{array}{c}t+9(10- \\ \text { Year) }\end{array}}{(4)}$

Rainfall

Quadratic

Rainfall $\mathrm{t}$

Rainfall t-1

Quadratic

Rainfall t-1

Rainfall t-2

Quadratic

Rainfall t-2

Linear \&

Quadratic

Temperature in

Different Years

Country Fixed

Effects

Year Fixed

Effects

Country Specific

Linear Time

Trends

Countries

Observations

R Squared

$$
\begin{aligned}
& -0.22 * \\
& (0.12)
\end{aligned}
$$$$
-0.66 * * *
$$

$0.005^{*}$

(0.0028)

$$
0.016^{* * *}
$$

$-0.66 * * *$

(0.25)

$0.012 * *$

(0.005)

(0.005)

$0.013^{* *}$

(0.006)

$-0.09$

$$
-0.12
$$

0.002

(0.002)

(0.004)

\section{$-0.21$}

(0.2)

$-0.19$

(0.27)

0.004

(0.004)

0.005

(0.006)

$$
\begin{gathered}
-0.35 * * \\
(0.13)
\end{gathered}
$$

$-0.48 * * *$

(0.19)

$0.009 * * *$

$0.011^{* *}$

(0.004)

$-0.27$

(0.19)

$-0.18$

(0.26)

0.006

\begin{tabular}{|c|c|c|c|}
\hline \multicolumn{4}{|c|}{ Polity Democratization between $\mathrm{t}-1$ and } \\
\hline $\mathrm{t}(1-$ Year) & $\begin{array}{l}\mathrm{t}+2(3- \\
\text { Year) }\end{array}$ & $\begin{array}{c}\mathrm{t}+4(5- \\
\text { Year) }\end{array}$ & $\begin{array}{c}\text { t+9 (10- } \\
\text { Year) }\end{array}$ \\
\hline$(5)$ & (6) & (7) & (8) \\
\hline $\begin{array}{l}-0.014 \\
(0.014)\end{array}$ & $\begin{array}{c}-0.052 * * * \\
(0.02)\end{array}$ & $\begin{array}{c}-0.053^{* * *} \\
(0.02)\end{array}$ & $\begin{array}{c}-0.036 \\
(0.023)\end{array}$ \\
\hline $\begin{array}{c}0.0003 \\
(0.0003)\end{array}$ & $\begin{array}{l}0.001 * * \\
(0.0005)\end{array}$ & $\begin{array}{l}0.0009 * \\
(0.0005)\end{array}$ & $\begin{array}{c}0.0006 \\
(0.0006)\end{array}$ \\
\hline $\begin{array}{l}-0.007 \\
(0.011)\end{array}$ & $\begin{array}{c}-0.022 \\
(0.017)\end{array}$ & $\begin{array}{c}-0.014 \\
(0.017)\end{array}$ & $\begin{array}{r}-0.005 \\
(0.02)\end{array}$ \\
\hline $\begin{array}{c}0.0001 \\
(0.0003)\end{array}$ & $\begin{array}{c}0.0003 \\
(0.0004)\end{array}$ & $\begin{array}{c}0.0002 \\
(0.0004)\end{array}$ & $\begin{array}{c}0.0001 \\
(0.0006)\end{array}$ \\
\hline $\begin{array}{c}-0.039 * * \\
(0.016)\end{array}$ & $\begin{array}{c}-0.066^{* * *} \\
(0.018)\end{array}$ & $\begin{array}{c}-0.033^{*} \\
(0.017)\end{array}$ & $\begin{array}{c}-0.015 \\
(0.023)\end{array}$ \\
\hline $\begin{array}{c}0.0009 * * \\
(0.0004)\end{array}$ & $\begin{array}{c}0.0013^{* * *} \\
(0.0005)\end{array}$ & $\begin{array}{c}0.0005 \\
(0.0004)\end{array}$ & $\begin{array}{c}0.0002 \\
(0.0005)\end{array}$ \\
\hline
\end{tabular}

(0.004)

0.003

(0.006)
Polity Project Democratization

Note: The left-hand-side variables in columns (1) to (4) are the improvements in the Polity Project polity score in autocracies over different time periods. The left-hand-side variable in column (1) is the improvement in the polity score between years $t-1$ and $t$; the left-hand-side variable in column (2) is the improvement in the polity score between years $t-1$ and $t+2$; the left-hand-side variable in column (3) is the improvement in the polity score between years $t-1$ and $t+4$; and the left-hand-side variable in column (4) is the improvement in the polity score between years $t-1$ and $t+9$. The left-hand-side variables in columns (5) to (8) are indicators for democratization over different time periods. The classification of democratic and autocratic regimes is based on Polity Project combined polity score. The left-hand-side variable in column (5) is an indicator variable that takes the value of 1 if a country that is an autocracy at $\mathrm{t}-1$ is a democracy at $\mathrm{t}$ and the value of 0 otherwise. The left-hand-side variable in column (6) is an indicator variable that takes the value of 1 if a country that is an autocracy at $t-1$ is a democracy at $t+2$ and the value of 0 otherwise. The left-hand-side variable in column (7) is an indicator variable that takes the value of 1 if a country that is an autocracy at $t-1$ is a democracy at $t+4$ and the value of 0 otherwise. The left-hand-side variable in column (8) is an indicator variable that takes the value of 1 if a country that is an autocracy at $\mathrm{t}-1$ is a democracy at $\mathrm{t}+9$ and the value of 0 otherwise. The included countries are all countries in Table 1 column (1) (countries with an average share of agricultural in GDP over the sample period in the top quintile of the distribution) with Polity Project data. The table reports robust standard errors clustered at the country level. * denotes significance at the $10 \%$ level; ${ }^{* *}$ cionificance at the $5 \%$ level: and $* * *$ cionificance at the $1 \%$ level 


\section{TABLE 4. Rainfall Shocks and Improvements in Freedom House Political Rights since 1960: From Short to Longer Term}

\begin{tabular}{|c|c|c|c|c|}
\hline & $\begin{array}{c}\text { Political Rights } \\
\text { Improvement } \\
\text { between t-1 } \\
\text { and t (1-Year) }\end{array}$ & $\begin{array}{c}\text { Political Rights } \\
\text { Improvement } \\
\text { between t-1 } \\
\text { and t+2 (3-Year) } \\
\end{array}$ & $\begin{array}{c}\text { Political Rights } \\
\text { Improvement } \\
\text { between } \mathrm{t}-1 \\
\text { and } \mathrm{t}+4 \text { (5- } \\
\text { Year) } \\
\end{array}$ & $\begin{array}{c}\text { Political Rights } \\
\text { Improvement } \\
\text { between t-1 } \\
\text { and t+9 (10- } \\
\text { Year) }\end{array}$ \\
\hline & (1) & (2) & (3) & (4) \\
\hline Rainfall $t$ & $\begin{array}{c}-0.059 * * \\
(0.027)\end{array}$ & $\begin{array}{c}-0.157^{* * *} \\
(0.047)\end{array}$ & $\begin{array}{c}-0.27^{* * *} \\
(0.068)\end{array}$ & $\begin{array}{c}-0.24 * * * \\
(0.07)\end{array}$ \\
\hline Quadratic Rainfall t & $\begin{array}{l}0.0011^{* *} \\
(0.0005)\end{array}$ & $\begin{array}{c}0.003 * * * \\
(0.001)\end{array}$ & $\begin{array}{l}0.006^{* * *} \\
(0.0015)\end{array}$ & $\begin{array}{l}0.004^{* * *} \\
(0.0016)\end{array}$ \\
\hline Rainfall t-1 & $\begin{array}{l}0.0017 \\
(0.022)\end{array}$ & $\begin{array}{l}-0.12^{* *} \\
(0.044)\end{array}$ & $\begin{array}{c}-0.13^{* *} \\
(0.06)\end{array}$ & $\begin{array}{c}-0.21^{* * *} \\
(0.07)\end{array}$ \\
\hline Quadratic Rainfall t-1 & $\begin{array}{c}0.0003 \\
(0.0005)\end{array}$ & $\begin{array}{c}0.0023 * * \\
(0.0009)\end{array}$ & $\begin{array}{l}0.0024^{*} \\
(0.0013)\end{array}$ & $\begin{array}{l}0.0035^{* *} \\
(0.0018)\end{array}$ \\
\hline Rainfall t-2 & $\begin{array}{c}-0.068 * * \\
(0.027)\end{array}$ & $\begin{array}{l}-0.15^{* * *} \\
(0.0482)\end{array}$ & $\begin{array}{l}-0.06 \\
(0.06)\end{array}$ & $\begin{array}{c}-0.23 * * * \\
(0.07)\end{array}$ \\
\hline Quadratic Rainfall t-2 & $\begin{array}{l}0.001^{* *} \\
(0.0006)\end{array}$ & $\begin{array}{c}0.0027^{* *} \\
(0.0011)\end{array}$ & $\begin{array}{c}0.0009 \\
(0.0014)\end{array}$ & $\begin{array}{c}0.0042^{* *} \\
(0.0019)\end{array}$ \\
\hline $\begin{array}{l}\text { Linear \& Quadratic } \\
\text { Temperature in } \\
\text { Different Years }\end{array}$ & $\mathrm{Y}$ & $\mathrm{Y}$ & $\mathrm{Y}$ & $Y$ \\
\hline Country Fixed Effects & Y & Y & Y & $Y$ \\
\hline Year Fixed Effects & Y & $\mathrm{Y}$ & $Y$ & Y \\
\hline $\begin{array}{l}\text { Country Specific } \\
\text { Linear Time Trends }\end{array}$ & $\mathrm{Y}$ & $\mathrm{Y}$ & $\mathrm{Y}$ & $\mathrm{Y}$ \\
\hline Countries & 31 & 31 & 31 & 31 \\
\hline Observations & 1,078 & 910 & 808 & 677 \\
\hline R Squared & 0.042 & 0.079 & 0.054 & 0.064 \\
\hline \multicolumn{5}{|c|}{$\begin{array}{l}\text { Note: The left-hand-side variables are the improvements in political rights over different time periods } \\
\text { measured by the Freedom House political rights index. The left-hand-side variable in column (1) is the } \\
\text { improvement in political rights between years } t-1 \text { and } t \text {; the left-hand-side variable in column (2) is the } \\
\text { improvement in political rights between years } t-1 \text { and } t+2 \text {; the left-hand-side variable in column (3) is the } \\
\text { improvement in political rights between years } t-1 \text { and } t+4 \text {; and the left-hand-side variable in column (4) } \\
\text { is the improvement in political rights between years } t-1 \text { and } t+9 \text {. The included countries are all countries } \\
\text { in Table } 1 \text { column (1) (countries with an average share of agricultural in GDP over the sample period in } \\
\text { the top quintile of the distribution) with Freedom House data. The table reports robust standard errors } \\
\text { clustered at the country level. * denotes significance at the } 10 \% \text { level; }{ }^{* *} \text { significance at the } 5 \% \text { level; } \\
\text { and }{ }^{* * *} \text { significance at the } 1 \% \text { level. }\end{array}$} \\
\hline
\end{tabular}




\section{FIGURE 1. Effect of Median Negative Rainfall Shock on the Probability of Short- and Longer-Term Przeworski et al. Democratization}

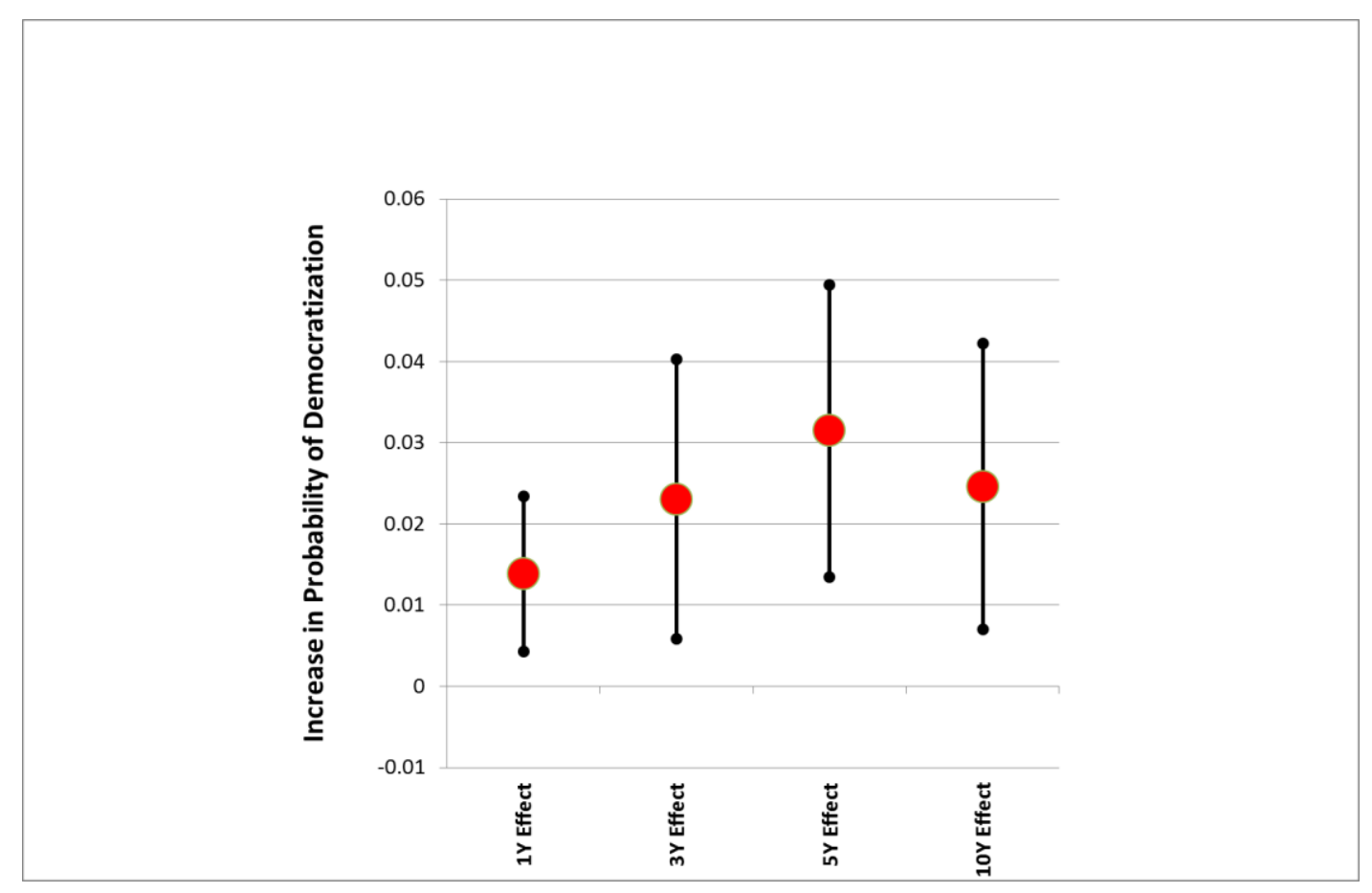

Note: Effect of a median negative rainfall shock in year $t$ on the probability of democratization in a country that is an autocracy in year $\mathrm{t}-1$. The dots are the point estimates for the probability that the country is a democracy by year $\mathrm{t}$ (1Y Effect); by year $\mathrm{t}+2$ (3Y Effect); by year $\mathrm{t}+4$ ( 5 Y Effect); and by year $\mathrm{t}+9$ (10Y Effect). The bands give the $90 \%$ confidence intervals. The classification of democratic and autocratic regimes is based on Bjornskov and Rode (2017) who extend the dataset of Cheibub, Gandhi, and Vreeland (2010) and Przeworski, Alvarez, Cheibub, and Limongi (2000). The median negative rainfall shock refers to a negative year-on-year shock of median size at the median level of rainfall. The confidence bands are based on robust standard errors clustered at the country level. 


\section{FIGURE 2. Effect of Rainfall on Real Agricultural Output and on the Probability of Democratization}

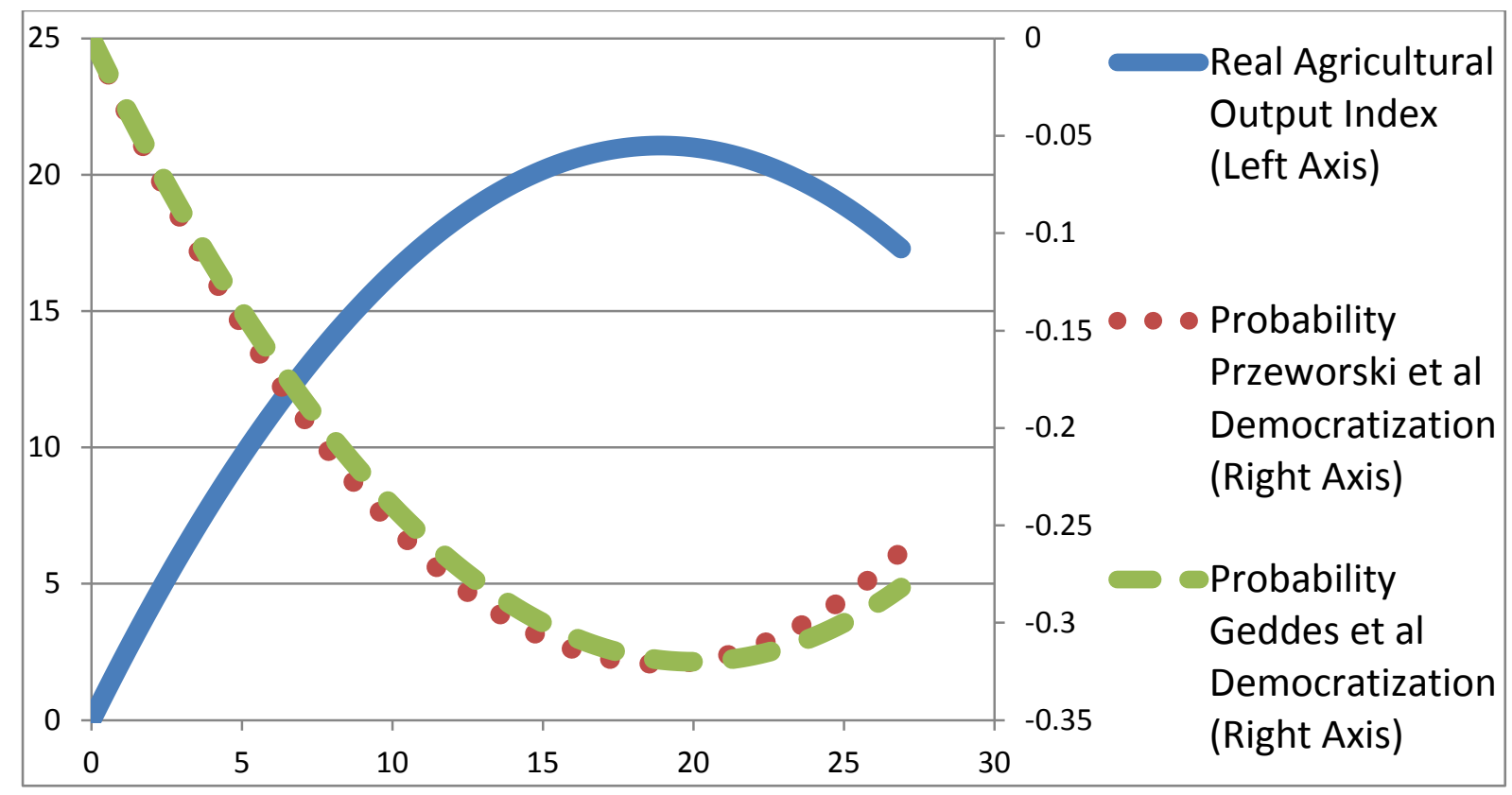

Note: Effect of rainfall on real agricultural output (solid line, measured on the left axis) and on the probability of democratization between years $\mathrm{t}-1$ and $\mathrm{t}$ (dashed and dotted lines, measured on the right axis). The classifications of democratic and autocratic regimes used are Przeworski, Alvarez, Cheibub, and Limongi (2000) (dotted line), as extended by Cheibub, Gandhi, and Vreeland (2010) and Bjornskov and Rode (2017), and Geddes, Wright, and Frantz (2014) (dashed line). The effect of rainfall on the probability of democratization is calculated using the effect of rainfall in year $t$ in column (1) of Table 2 for the Przeworski et al. democratization indicator. For the Geddes et al. democratization indicator, the effect of rainfall on the probability of democratization is calculated using the effect of rainfall in year t-1 in column (5) of Table 2. This is because of Geddes et al.'s unconventional start date for democratic regime transitions, see page 9 in the main text for details. Real agricultural output is an index with base year 2004-2006 and rainfall is measured in $\mathrm{dm}$. 


\section{FIGURE 3. Effect of Median Negative Rainfall Shock on the Probability of Short- and Longer-Term Geddes et al. Democratization}

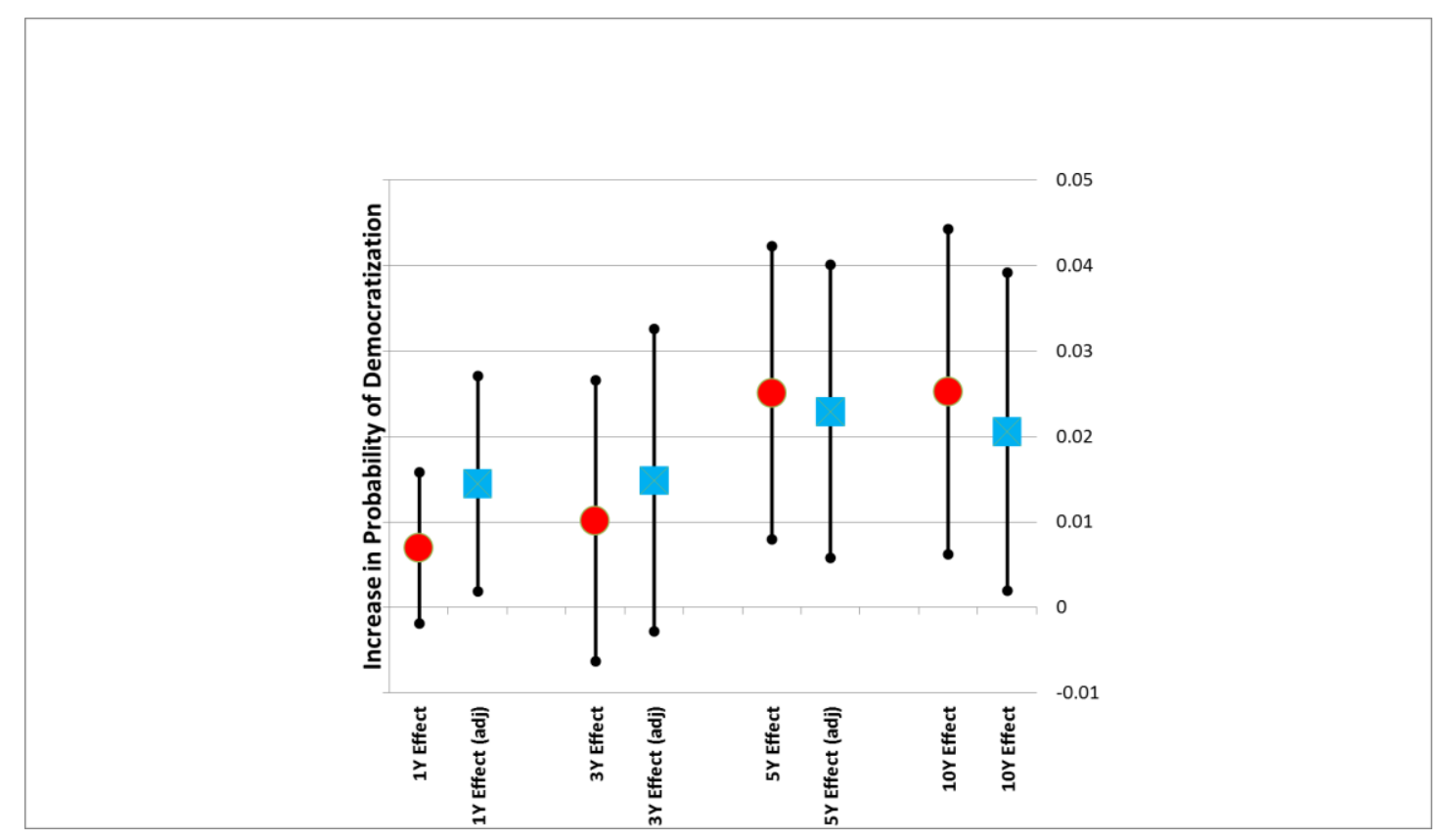

Note: Effect of a median negative rainfall shock in year $t$ on the probability of democratization in a country that is an autocracy in year $\mathrm{t}-1$. The red dots are the point estimates for the probability that the country is a democracy by year $t$ (1Y Effect); by year $t+2$ (3Y Effect); by year $t+4$ ( 5 Y Effect); and by year $t+9$ (10Y Effect). The bands give the $90 \%$ confidence intervals. The classification of democratic and autocratic regimes is based on Geddes, Wright, and Frantz (2014). The blue dots and corresponding $90 \%$ confidence bands are based on estimations with recoded Geddes, Wright, and Frantz data using the conventional start date for regime transitions, see page 9 in the main text for details. The median negative rainfall shock refers to a negative yearon-year shock of median size at the median level of rainfall. The confidence bands are based on robust standard errors clustered at the country level. 


\section{FIGURE 4. Effect of Median Negative Rainfall Shock on the Short- and Longer-Term Improvement in Polity Project Democracy Score}

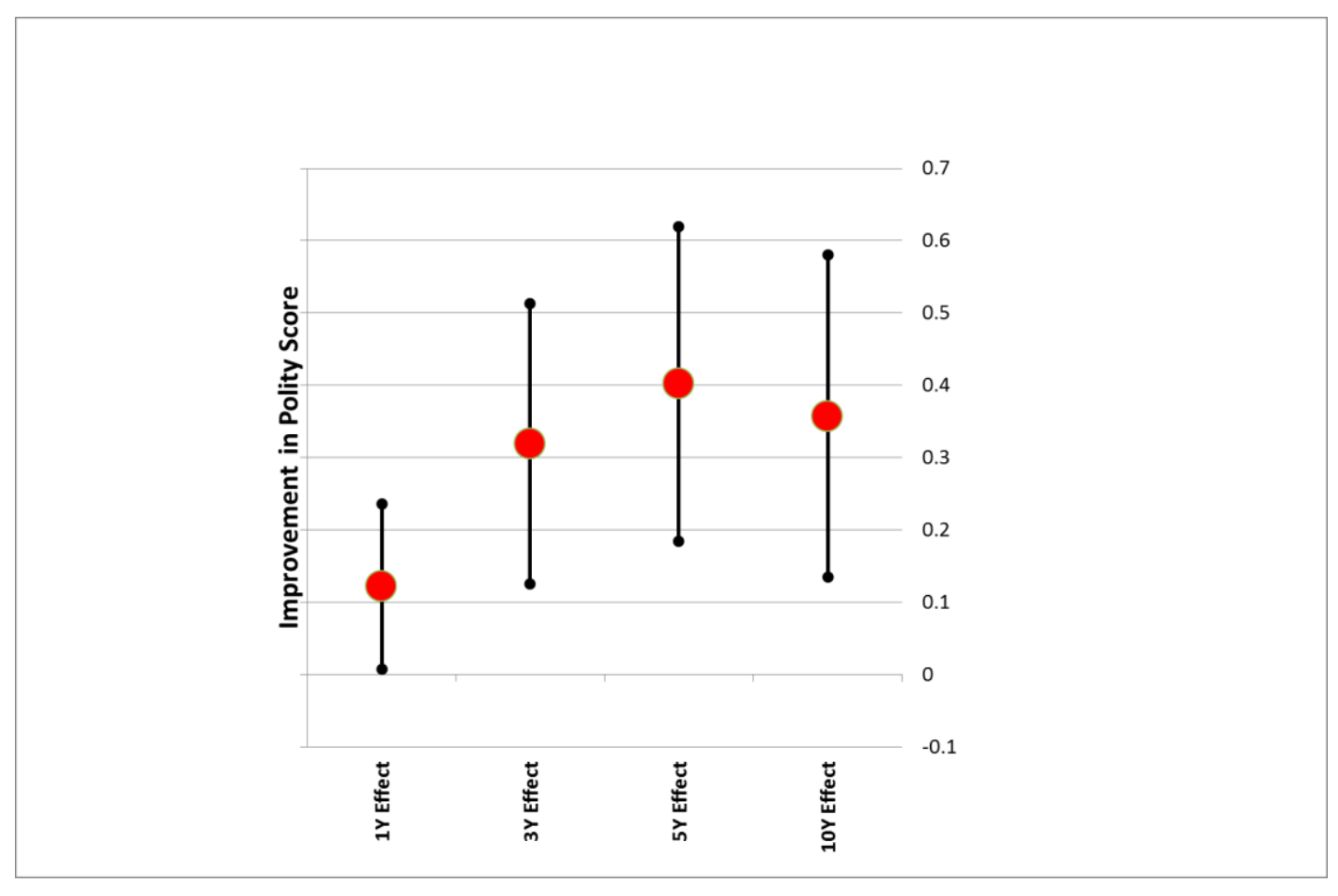

Note: Effect of a median negative rainfall shock in year $t$ on the improvement in the Polity Project polity score in a country that is an autocracy in year $\mathrm{t}-1$. The dots are the point estimates for the improvements in the polity score by year $t$ (1Y Effect); by year $t+2$ (3Y Effect); by year $t+4$ (5Y Effect); and by year $t+9$ (10Y Effect). The bands give the $90 \%$ confidence intervals. The polity score varies between -10 and +10 . Autocracies are countries with a score smaller or equal -1 . The median negative rainfall shock refers to a negative year-on-year shock of median size at the median level of rainfall. The confidence bands are based on robust standard errors clustered at the country level. 


\section{FIGURE 5. Effect of Rainfall on Real Agricultural Output and on the Polity Democratic Improvement}

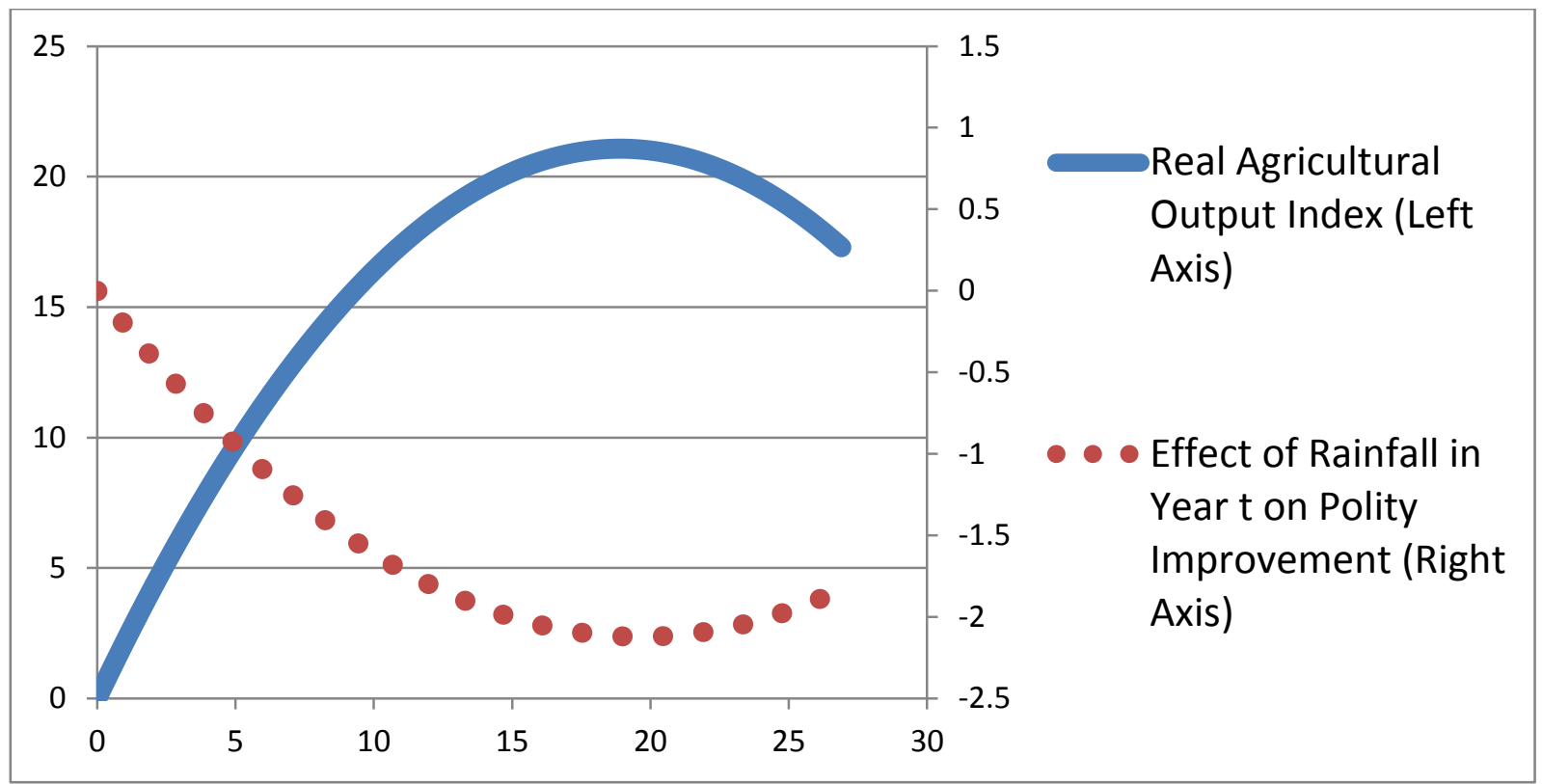

Note: Effect of rainfall on real agricultural output (solid line, measured on the left axis) and on the democratic improvement between years t-1 and t calculated using the Polity Project polity score (dotted line, measured on the right axis). The effect of rainfall on democratic improvements is calculated using the effect of rainfall in year $t$ in column (1) of Table 3. Real agricultural output is an index with base year 2004-2006 and rainfall is measured in $\mathrm{dm}$. 


\section{FIGURE 6. Effect of Median Negative Rainfall Shock on the Probability of Short- and Longer-Term Polity Project Democratization}

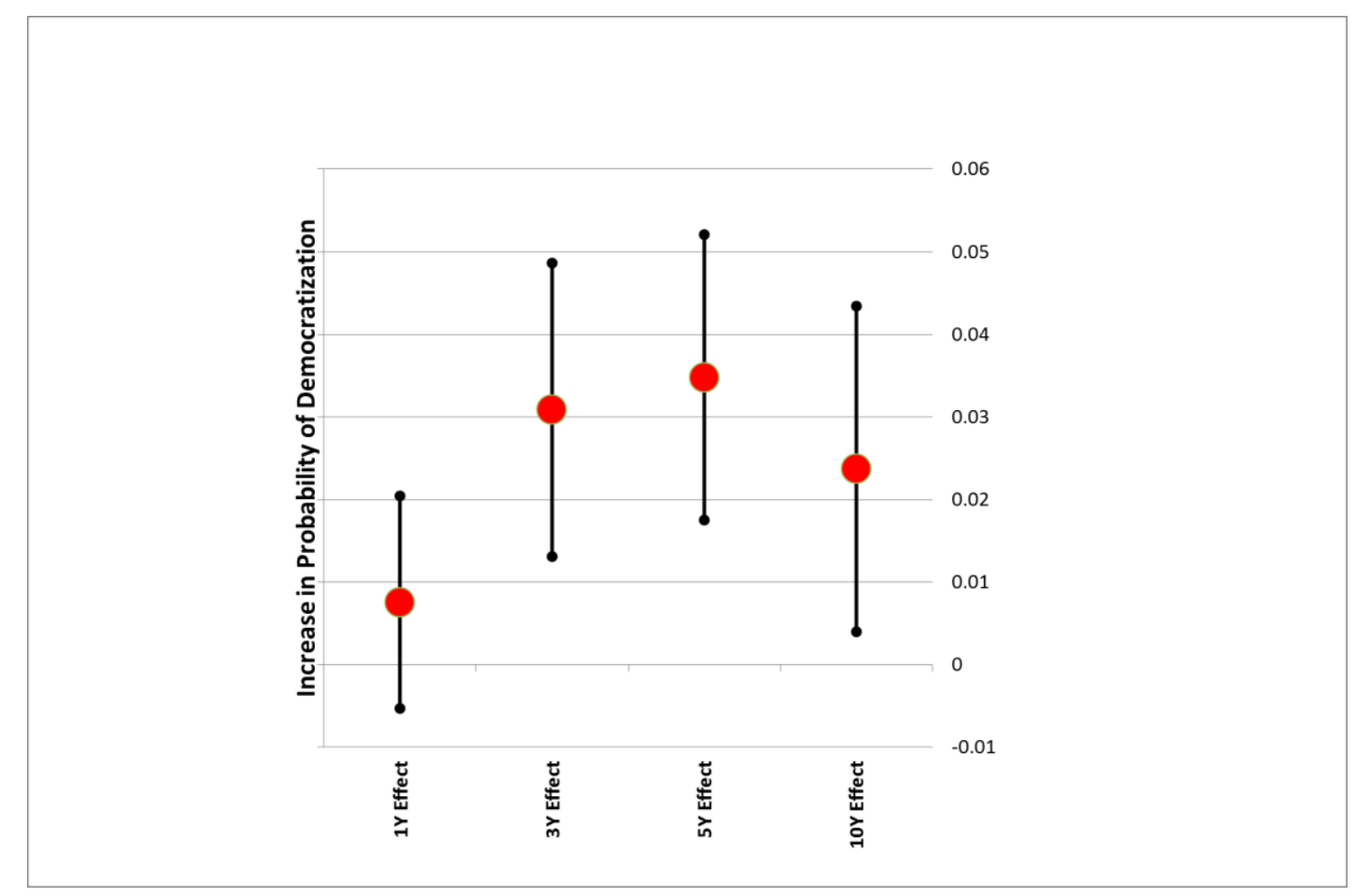

Note: Effect of a median negative rainfall shock in year $t$ on the probability of democratization in a country that is an autocracy in year $\mathrm{t}-1$. The dots are the point estimates for the probability that the country is a democracy by year $t$ (1Y Effect); by year $t+2$ (3Y Effect); by year $t+4$ ( $5 Y$ Effect); and by year $t+9$ (10Y Effect). The bands give the $90 \%$ confidence intervals. The classification of democratic and autocratic regimes is based on the Polity Project polity score. Autocracies are countries with a score smaller equal -1 and democracies are countries with a score greater equal +1 . The median negative rainfall shock refers to a negative year-on-year shock of median size at the median level of rainfall. The confidence bands are based on robust standard errors clustered at the country level. 


\section{FIGURE 7. Effect of Median Negative Rainfall Shock on the Short- and Longer-Term Improvement in Freedom House Political Rights}

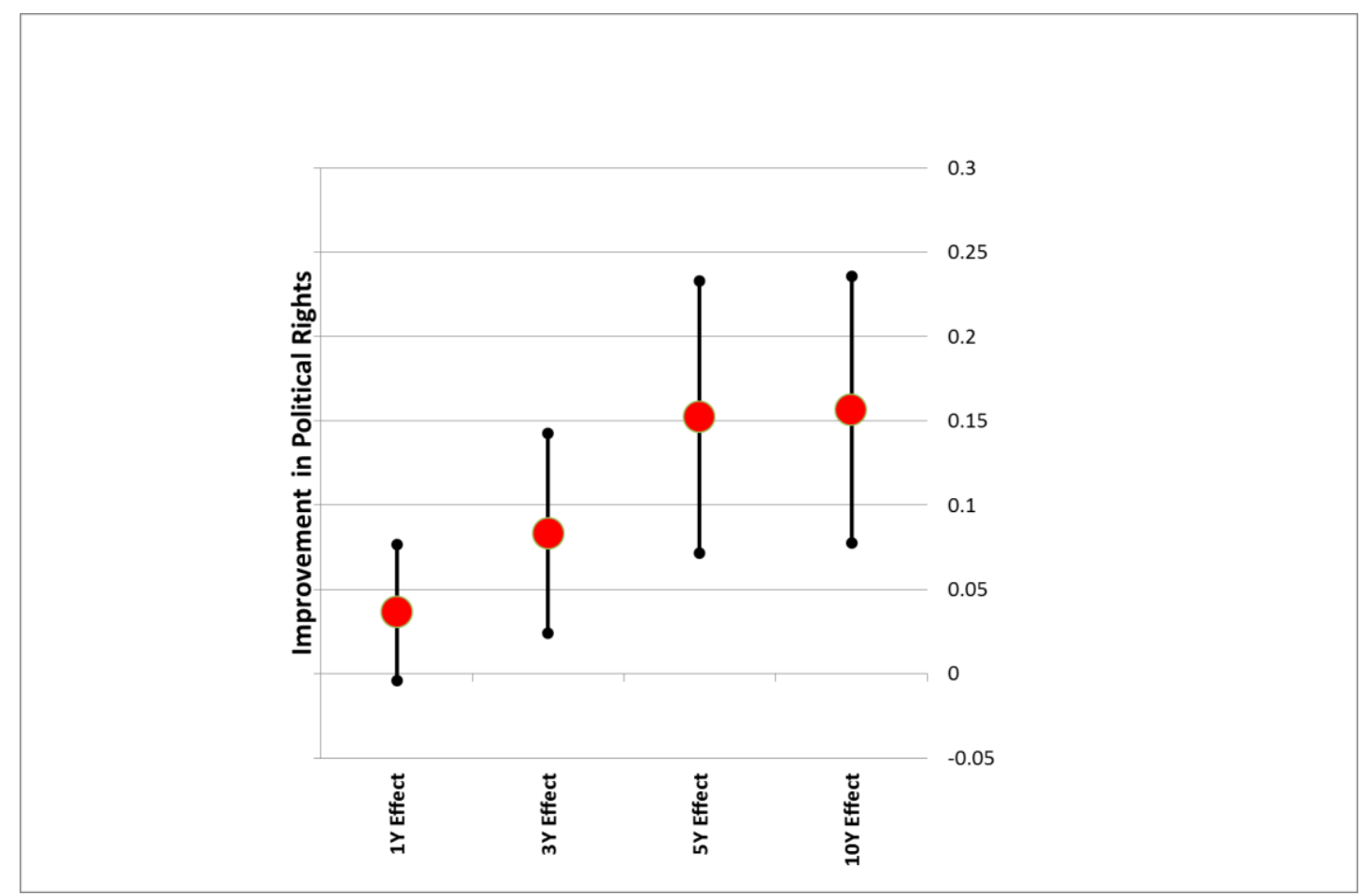

Note: Effect of a median negative rainfall shock in year $t$ on the improvement in the Freedom House political rights index in a country that is an autocracy in year $\mathrm{t}-1$. The dots are the point estimates for the improvement in the Freedom House political rights index by year $t$ (1Y Effect); by year $t+2$ (3Y Effect); by year $t+4$ ( $5 Y$ Effect); and by year $t+9$ (10Y Effect). The Freedom House political rights index varies between 1 and 7 . The median negative rainfall shock refers to a negative year-on-year shock of median size at the median level of rainfall. The confidence bands are based on robust standard errors clustered at the country level. 


\section{APPENDIX TABLE 1. Rainfall Shocks and Democratization since 1960 in Sub-Saharan Africa: From Short to Longer Term}

Przeworski et al. Democratization

Przeworski et al. Democratization between t-1 and

$\frac{t(1-Y e a r)}{(1)} \frac{\begin{array}{c}t+2(3- \\ \text { Year) }\end{array}}{(2)} \frac{t+4(5-Y e a r)}{(3)} \frac{t+9(10-Y e a r)}{(4)}$

Rainfall t

Quadratic

Rainfall $\mathrm{t}$

Rainfall t-1

Quadratic

Rainfall t-1

Rainfall t-2

Quadratic

Rainfall t-2

Rainfall t-3

Quadratic

Rainfall t-3

Linear \&

Quadratic

Temperature in

Different Years

Country Fixed

Effects

Year Fixed

Effects

Country Specific

Linear Time

Trends

Countries

Observations

R Squared

$-0.0361 * *$

(0.0169)

$0.0011^{* *}$

(0.0006)

0.0195

(0.0128)

$-0.0293$

(0.0194)

0.0007

(0.0005)

$-0.0005^{*}$

(0.0003)

$-0.0119$

(0.0191)

$\begin{array}{ll}-0.0154 & -0.0184 \\ (0.0145) & (0.0206)\end{array}$

0.0002

(0.0004)

0.0002

(0.0003)

0.0006

$\begin{array}{ll}-0.0037 & -0.0217\end{array}$

(0.0109)

(0.0177)

0.0002

(0.0003)

0.0007

(0.0005)

Y

Y

Y

Y

Y

Y

19

741

0.035 $\begin{array}{ll}-0.0457 * * & -0.0047\end{array}$

(0.0217) (0.0181)

$0.0011^{* *} \quad 0.0003$

(0.0005) (0.0005)

$-0.0285-0.0352 * *$

(0.0176)

$(0.0194)$

$0.0010 * *$

(0.0005)

(0.0005)

$-0.0125$

(0.0185) (0.0172)

0.0006

0.0005

(0.0004)

0.0031

(0.0169)

$-0.0134$

0.0000

(0.0004)

$(0.0004)$

Y

Y

\section{Y}

Y

Y

Y

Y

695

619

0.039

0.031
Geddes et al. Democratization

Geddes et al. Democratization between $\mathrm{t}-1$ and

\begin{tabular}{|c|c|c|c|}
\hline $\begin{array}{l}\mathrm{t}(1- \\
\text { Year) }\end{array}$ & $\begin{array}{l}t+2(3- \\
\text { Year) }\end{array}$ & $\begin{array}{c}t+4(5- \\
\text { Year) }\end{array}$ & $t+9$ (10-Year) \\
\hline (5) & (6) & (7) & (8) \\
\hline $\begin{array}{c}-0.0043 \\
(0.0111)\end{array}$ & $\begin{array}{l}-0.0024 \\
(0.0168)\end{array}$ & $\begin{array}{l}-0.0290 \\
(0.0181)\end{array}$ & $\begin{array}{l}-0.0290 \\
(0.0189)\end{array}$ \\
\hline $\begin{array}{l}-0.0000 \\
(0.0003)\end{array}$ & $\begin{array}{c}0.0001 \\
(0.0004)\end{array}$ & $\begin{array}{c}0.0005 \\
(0.0004)\end{array}$ & $\begin{array}{c}0.0007 \\
(0.0005)\end{array}$ \\
\hline $\begin{array}{c}-0.0399 * * \\
(0.0172)\end{array}$ & $\begin{array}{c}-0.0231 \\
(0.0198)\end{array}$ & $\begin{array}{c}-0.0485^{* * *} \\
(0.0183)\end{array}$ & $\begin{array}{l}-0.0078 \\
(0.0159)\end{array}$ \\
\hline $\begin{array}{c}0.0012^{* *} \\
(0.0005)\end{array}$ & $\begin{array}{c}0.0007 \\
(0.0005)\end{array}$ & $\begin{array}{c}0.0013^{* * *} \\
(0.0004)\end{array}$ & $\begin{array}{c}0.0003 \\
(0.0004)\end{array}$ \\
\hline $\begin{array}{l}0.0234 * \\
(0.0135)\end{array}$ & $\begin{array}{l}-0.0106 \\
(0.0179)\end{array}$ & $\begin{array}{l}-0.0248 \\
(0.0166)\end{array}$ & $\begin{array}{c}-0.0420 * * \\
(0.0173)\end{array}$ \\
\hline $\begin{array}{l}-0.0005^{*} \\
(0.0003)\end{array}$ & $\begin{array}{c}0.0002 \\
(0.0004)\end{array}$ & $\begin{array}{l}0.0007^{*} \\
(0.0004)\end{array}$ & $\begin{array}{c}0.0012^{* * *} \\
(0.0004)\end{array}$ \\
\hline $\begin{array}{c}-0.0241 \\
(0.0158)\end{array}$ & $\begin{array}{c}-0.0441^{* * *} \\
(0.0169)\end{array}$ & $\begin{array}{c}-0.0275 \\
(0.0167)\end{array}$ & $\begin{array}{c}0.0097 \\
(0.0166)\end{array}$ \\
\hline $\begin{array}{c}0.0006 \\
(0.0004)\end{array}$ & $\begin{array}{c}0.0011^{* * *} \\
(0.0004)\end{array}$ & $\begin{array}{c}0.0009 * * \\
(0.0004)\end{array}$ & $\begin{array}{c}-0.0001 \\
(0.0004)\end{array}$ \\
\hline
\end{tabular}

Y

Y

Y

Y

Y

Y

Y

Y

Y

Y

Y

19

19

19

19

742

718

698

632

0.038

0.026

0.039

0.029

Note: The left-hand-side variable in columns (1) and (5) is an indicator variable that takes the value of 1 if a country that is an autocracy at $\mathrm{t}-1$ is a democracy at $\mathrm{t}$ and the value of 0 otherwise. The left-hand-side variable in columns (2) and (6) is an indicator variable that takes the value of 1 if a country that is an autocracy at $t-1$ is a democracy at $t+2$ and the value of 0 otherwise. The lefthand-side variable in columns (3) and (7) is an indicator variable that takes the value of 1 if a country that is an autocracy at t-1 is a democracy at $t+4$ and the value of 0 otherwise. The left-hand-side variable in columns (4) and (8) is an indicator variable that takes the value of 1 if a country that is an autocracy at $t-1$ is a democracy at $t+9$ and the value of 0 otherwise. The classification of democratic and autocratic regimes in columns (5)-(8) is based on Geddes, Wright, and Frantz (2014). The classification of democratic and autocratic regimes in columns (1)-(4) is based on Bjornskov and Rode (2017) who extend the dataset of Cheibub, Gandhi, and Vreeland (2010) and Przeworski, Alvarez, Cheibub, and Limongi (2000). The countries included are the Sub-Saharan African countries in Table 1 column (1) (countries with an average share of agricultural in GDP over the sample period in the top quintile of the distribution) with democratization data. The table reports robust standard errors clustered at the country level. * denotes significance at the $10 \%$ level; ${ }^{* *}$ significance at the $5 \%$ level; and ${ }^{* * *}$ significance at the $1 \%$ level. 


\section{APPENDIX TABLE 2. Rainfall Shocks and Democratization since 1960 Outside Sub- Saharan Africa: From Short to Longer Term}

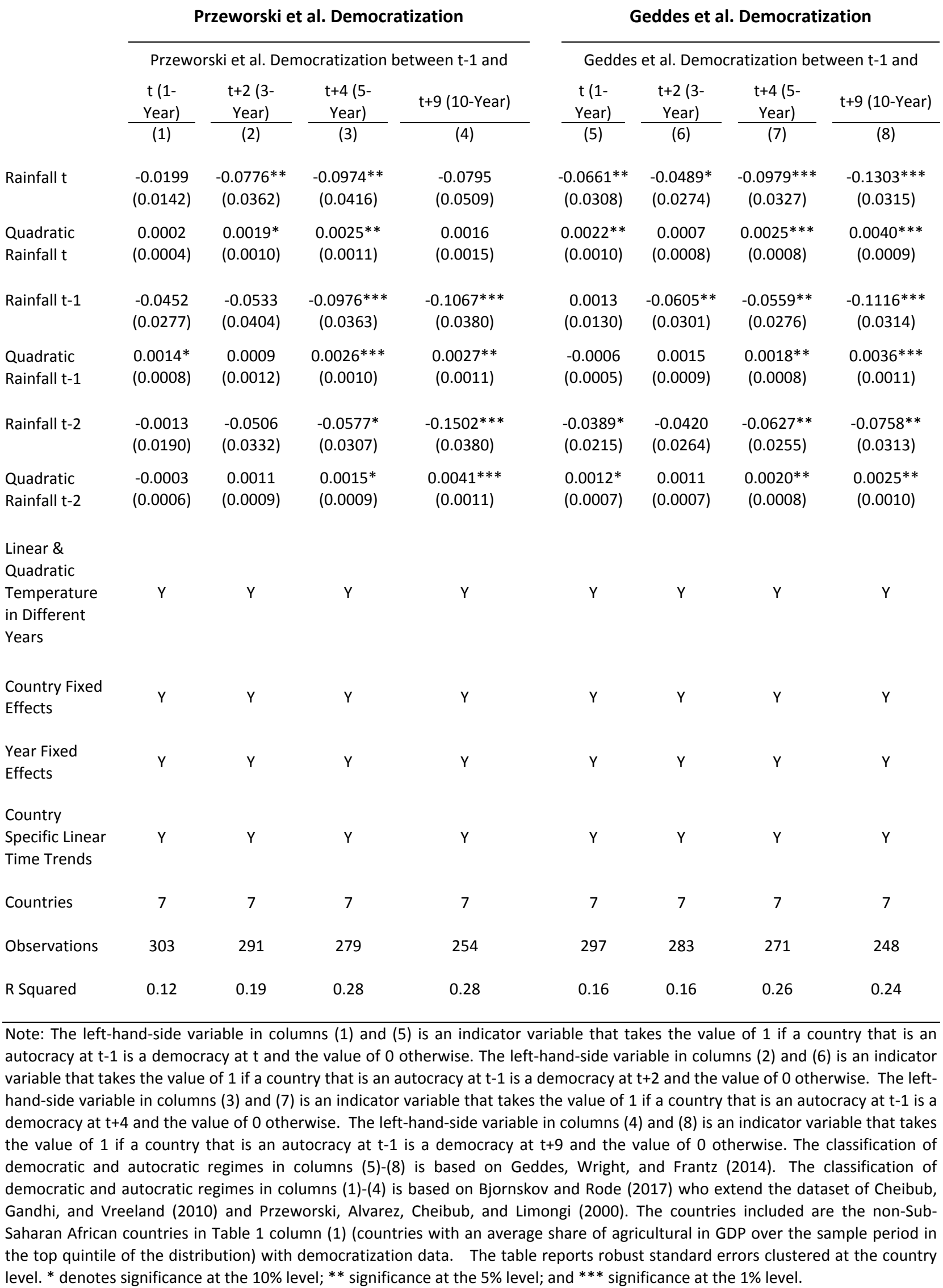




\section{APPENDIX TABLE 3. Rainfall Shocks and Democratization since 1980: From Short to Longer Term}

Przeworski et al. Democratization

Przeworski et al. Democratization between t-1 and

$\mathrm{t}$ (1-Year)

(1)

Rainfall $\mathrm{t}$

Quadratic
Rainfall

Rainfall t-1

Quadratic

Rainfall t-1

Rainfall t-2

Quadratic

Rainfall t-2

Rainfall t-3

Quadratic

Rainfall t-3

Linear \&

Quadratic

Temperature in

Different Years

Country Fixed

Effects

Year Fixed

Effects

Country Specific Linear Time

Trends

Countries

Observations

R Squared

$$
-0.0651^{* *}
$$$$
\text { (0.0254) }
$$

$0.0020^{* *}$

(0.0009)

0.0220

(0.0155)

$-0.0006$

(0.0005)

$-0.0170$

(0.0210)

$-0.0436$

0.0002

(0.0005)

0.0012

$-0.0207$

(0.0009)

(0.0168)

$-0.0175$

(0.0250)

0.0006

(0.0005)

0.0005

(0.0008)
Y

Y

Y

Y

Y

29

653

0.056

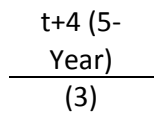

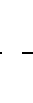

t+9 (10-Year)

(4)

$-0.0136$

(0.0315)

(0.0310)

0.0008

(0.0010)

(0.0009)

$-0.0259$

(0.0284)

$-0.0504 *$

(0.0300)

$0.0017^{*}$

(0.0010)

(0.0009)

$-0.0490 *$

(0.0263)

$0.0016^{* *}$

(0.0008)

$-0.0009$

(0.0279)

0.0001

(0.0008)
$-0.0446$

(0.0317)

0.0013

(0.0011)

0.0188

(0.0439)

$-0.0005$

(0.0015)
Geddes et al. Democratization

Geddes et al. Democratization between t-1 and

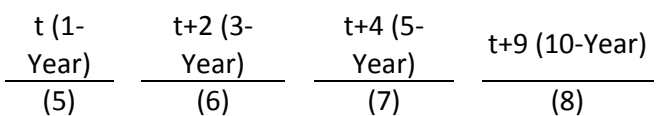

$\begin{array}{llll}0.0015 & -0.0313 & -0.0625 * * & -0.0573 * \\ (0.0160) & (0.0236) & (0.0266) & (0.0317)\end{array}$

$\begin{array}{llll}(0.0160) & (0.0236) & (0.0266) & (0.0317)\end{array}$

$\begin{array}{llll}-0.0003 & 0.0007 & 0.0013 * & 0.0016\end{array}$

$\begin{array}{llll}(0.0005) & (0.0007) \quad(0.0008) & (0.0010)\end{array}$

$\begin{array}{llll}-0.0719 * * * & -0.0651 * * & -0.0898 * * * & -0.0613 * *\end{array}$

$\begin{array}{llll}(0.0255) & (0.0271) & (0.0284) & \text { (0.0261) }\end{array}$

$\begin{array}{llll}0.0023 * * * & 0.0020 * * & 0.0028 * * * & 0.0019 * * *\end{array}$

$\begin{array}{llll}(0.0009) & (0.0008) & (0.0009) & (0.0008)\end{array}$

$\begin{array}{llll}0.0175 & -0.0231 & -0.0490 * & -0.0507\end{array}$

$\begin{array}{llll}(0.0144) & (0.0220) & (0.0268) & \text { (0.0317) }\end{array}$

$\begin{array}{llll}-0.0007 & 0.0003 & 0.0014 & 0.0012\end{array}$

$\begin{array}{llll}(0.0004) & (0.0006) \quad(0.0008) & (0.0010)\end{array}$

$\begin{array}{llll}-0.0293 & -0.0673 * * & -0.0332 & 0.0175\end{array}$

$\begin{array}{llll}(0.0210) & \text { (0.0271) (0.0269) }\end{array}$

$\begin{array}{llll}0.0007 & 0.0019 * * & 0.0011 & -0.0005\end{array}$

$\begin{array}{llll}(0.0006) & (0.0008) & (0.0008) & (0.0012)\end{array}$

Note: The left-hand-side variable in columns (1) and (5) is an indicator variable that takes the value of 1 if a country that is an autocracy at $t-1$ is a democracy at $t$ and the value of 0 otherwise. The left-hand-side variable in columns (2) and (6) is an indicator variable that takes the value of 1 if a country that is an autocracy at $t-1$ is a democracy at $t+2$ and the value of 0 otherwise. The lefthand-side variable in columns ( 3 ) and (7) is an indicator variable that takes the value of 1 if a country that is an autocracy at $t-1$ is a democracy at $t+4$ and the value of 0 otherwise. The left-hand-side variable in columns (4) and (8) is an indicator variable that takes the value of 1 if a country that is an autocracy at $t-1$ is a democracy at $t+9$ and the value of 0 otherwise. The classification of democratic and autocratic regimes in columns (5)-(8) is based on Geddes, Wright, and Frantz (2014). The classification of democratic and autocratic regimes in columns (1)-(4) is based on Bjornskov and Rode (2017) who extend the dataset of Cheibub, Gandhi, and Vreeland (2010) and Przeworski, Alvarez, Cheibub, and Limongi (2000). The countries included are those with an average share of agricultural in GDP over the sample period (1980-2013) in the top quintile of the distribution and with democratization data. The table reports one additional rainfall (and temperature) lag as the additional rainfall lag is soometimes statistically significant. The table reports robust standard errors clustered at the country level. * denotes significance at the $10 \%$ level; ${ }^{* *}$ significance at the $5 \%$ level; and ${ }^{* * *}$ significance at the $1 \%$ level. 


\section{APPENDIX TABLE 4. Agricultural Rainfall Shocks and Democratization since 1980: From Short to Longer Term}

\begin{tabular}{|c|c|c|c|c|c|c|c|c|}
\hline & \multicolumn{4}{|c|}{ Przeworski et al. Democratization } & \multicolumn{4}{|c|}{ Geddes et al. Democratization } \\
\hline & \multicolumn{4}{|c|}{ Przeworski et al. Democratization between $\mathrm{t}-1$ and } & \multicolumn{4}{|c|}{ Geddes et al. Democratization between $\mathrm{t}-1$ and } \\
\hline & $\begin{array}{l}\mathrm{t}(1- \\
\text { Year) }\end{array}$ & $\begin{array}{c}\mathrm{t}+2(3- \\
\text { Year) }\end{array}$ & $\begin{array}{c}\mathrm{t}+4(5- \\
\text { Year })\end{array}$ & $t+9$ (10-Year) & $\begin{array}{l}\mathrm{t}(1- \\
\text { Year })\end{array}$ & $\begin{array}{c}\mathrm{t}+2(3- \\
\text { Year) }\end{array}$ & $\begin{array}{c}t+4(5- \\
\text { Year })\end{array}$ & $\begin{array}{c}\mathrm{t}+9(10- \\
\text { Year) }\end{array}$ \\
\hline & (1) & (2) & (3) & (4) & (5) & (6) & (7) & (8) \\
\hline $\begin{array}{l}\text { Agricultural } \\
\text { Rainfall t }\end{array}$ & $\begin{array}{c}-0.0637^{* *} \\
(0.0302)\end{array}$ & $\begin{array}{c}-0.0703^{* *} \\
(0.0323)\end{array}$ & $\begin{array}{c}-0.0571^{*} \\
(0.0320)\end{array}$ & $\begin{array}{l}-0.0184 \\
(0.0367)\end{array}$ & $\begin{array}{l}-0.0165 \\
(0.0216)\end{array}$ & $\begin{array}{c}-0.0684^{* *} \\
(0.0345)\end{array}$ & $\begin{array}{c}-0.0263 \\
(0.0368)\end{array}$ & $\begin{array}{l}-0.0344 \\
(0.0417)\end{array}$ \\
\hline $\begin{array}{l}\text { Quadratic Agric. } \\
\text { Rainfall t }\end{array}$ & $\begin{array}{c}0.0032^{* *} \\
(0.0015)\end{array}$ & $\begin{array}{c}0.0035^{* *} \\
(0.0014)\end{array}$ & $\begin{array}{c}0.0032^{* *} \\
(0.0014)\end{array}$ & $\begin{array}{c}0.0016 \\
(0.0016)\end{array}$ & $\begin{array}{c}0.0007 \\
(0.0009)\end{array}$ & $\begin{array}{c}0.0034^{* *} \\
(0.0016)\end{array}$ & $\begin{array}{c}0.0008 \\
(0.0017)\end{array}$ & $\begin{array}{c}0.0016 \\
(0.0021)\end{array}$ \\
\hline $\begin{array}{l}\text { Agricultural } \\
\text { Rainfall t-1 }\end{array}$ & $\begin{array}{c}0.0151 \\
(0.0245)\end{array}$ & $\begin{array}{l}-0.0327 \\
(0.0339)\end{array}$ & $\begin{array}{c}0.0170 \\
(0.0395)\end{array}$ & $\begin{array}{l}-0.0585 \\
(0.0434)\end{array}$ & $\begin{array}{c}-0.0722^{* * *} \\
(0.0272)\end{array}$ & $\begin{array}{c}-0.0516^{*} \\
(0.0278)\end{array}$ & $\begin{array}{c}-0.0642^{* *} \\
(0.0313)\end{array}$ & $\begin{array}{c}-0.0749 * * \\
(0.0377)\end{array}$ \\
\hline $\begin{array}{l}\text { Quadratic Agric. } \\
\text { Rainfall t-1 }\end{array}$ & $\begin{array}{c}-0.0003 \\
(0.0013)\end{array}$ & $\begin{array}{c}0.0015 \\
(0.0017)\end{array}$ & $\begin{array}{c}-0.0002 \\
(0.0020)\end{array}$ & $\begin{array}{c}0.0025 \\
(0.0022)\end{array}$ & $\begin{array}{c}0.0034^{* *} \\
(0.0014)\end{array}$ & $\begin{array}{c}0.0025^{* *} \\
(0.0012)\end{array}$ & $\begin{array}{c}0.0034^{* *} \\
(0.0014)\end{array}$ & $\begin{array}{c}0.0034^{* *} \\
(0.0017)\end{array}$ \\
\hline $\begin{array}{l}\text { Agricultural } \\
\text { Rainfall t-2 }\end{array}$ & $\begin{array}{c}-0.0262 \\
(0.0296)\end{array}$ & $\begin{array}{c}-0.0372 \\
(0.0390)\end{array}$ & $\begin{array}{l}-0.0339 \\
(0.0360)\end{array}$ & $\begin{array}{c}-0.1023 * * * \\
(0.0363)\end{array}$ & $\begin{array}{c}0.0072 \\
(0.0203)\end{array}$ & $\begin{array}{c}0.0250 \\
(0.0277)\end{array}$ & $\begin{array}{c}-0.0399 \\
(0.0349)\end{array}$ & $\begin{array}{c}-0.1080^{* * *} \\
(0.0381)\end{array}$ \\
\hline $\begin{array}{l}\text { Quadratic Agric. } \\
\text { Rainfall t-2 }\end{array}$ & $\begin{array}{c}0.0005 \\
(0.0012)\end{array}$ & $\begin{array}{c}0.0015 \\
(0.0018)\end{array}$ & $\begin{array}{c}0.0016 \\
(0.0016)\end{array}$ & $\begin{array}{c}0.0054^{* * *} \\
(0.0017)\end{array}$ & $\begin{array}{l}-0.0000 \\
(0.0009)\end{array}$ & $\begin{array}{l}-0.0015 \\
(0.0012)\end{array}$ & $\begin{array}{c}0.0028 \\
(0.0017)\end{array}$ & $\begin{array}{c}0.0052^{* * *} \\
(0.0018)\end{array}$ \\
\hline $\begin{array}{l}\text { Agricultural } \\
\text { Rainfall t-3 }\end{array}$ & $\begin{array}{l}-0.0127 \\
(0.0236)\end{array}$ & $\begin{array}{c}0.0044 \\
(0.0350)\end{array}$ & $\begin{array}{l}-0.0098 \\
(0.0350)\end{array}$ & $\begin{array}{l}-0.0083 \\
(0.0452)\end{array}$ & $\begin{array}{l}-0.0083 \\
(0.0249)\end{array}$ & $\begin{array}{l}-0.0487 \\
(0.0347)\end{array}$ & $\begin{array}{l}-0.0192 \\
(0.0367)\end{array}$ & $\begin{array}{l}-0.0287 \\
(0.0441)\end{array}$ \\
\hline $\begin{array}{l}\text { Quadratic Agric. } \\
\text { Rainfall t-3 }\end{array}$ & $\begin{array}{c}0.0008 \\
(0.0011)\end{array}$ & $\begin{array}{c}0.0001 \\
(0.0016)\end{array}$ & $\begin{array}{c}0.0011 \\
(0.0016)\end{array}$ & $\begin{array}{c}0.0014 \\
(0.0021)\end{array}$ & $\begin{array}{c}0.0002 \\
(0.0011)\end{array}$ & $\begin{array}{c}0.0024 \\
(0.0016)\end{array}$ & $\begin{array}{c}0.0010 \\
(0.0017)\end{array}$ & $\begin{array}{c}0.0021 \\
(0.0021)\end{array}$ \\
\hline $\begin{array}{l}\text { Linear \& } \\
\text { Quadratic } \\
\text { Temperature in } \\
\text { Different Years }\end{array}$ & $\mathrm{Y}$ & $\mathrm{Y}$ & Y & $\mathrm{Y}$ & $\mathrm{Y}$ & $\mathrm{Y}$ & $\mathrm{Y}$ & $\mathrm{Y}$ \\
\hline $\begin{array}{l}\text { Country Fixed } \\
\text { Effects }\end{array}$ & $\mathrm{Y}$ & $\mathrm{Y}$ & $\mathrm{Y}$ & $\mathrm{Y}$ & $\mathrm{Y}$ & $\mathrm{Y}$ & $\mathrm{Y}$ & $\mathrm{Y}$ \\
\hline Year Fixed Effects & $\mathrm{Y}$ & $\mathrm{Y}$ & $\mathrm{Y}$ & $\mathrm{Y}$ & $\mathrm{Y}$ & $\mathrm{Y}$ & $\mathrm{Y}$ & $\mathrm{Y}$ \\
\hline $\begin{array}{l}\text { Country Specific } \\
\text { Linear Time } \\
\text { Trends }\end{array}$ & $\mathrm{Y}$ & $\mathrm{Y}$ & $\mathrm{Y}$ & $\mathrm{Y}$ & $\mathrm{Y}$ & $\mathrm{Y}$ & $\mathrm{Y}$ & $\mathrm{Y}$ \\
\hline Countries & 29 & 29 & 29 & 29 & 29 & 29 & 29 & 29 \\
\hline Observations & 653 & 615 & 577 & 477 & 653 & 614 & 574 & 481 \\
\hline R Squared & 0.049 & 0.041 & 0.057 & 0.096 & 0.048 & 0.044 & 0.057 & 0.078 \\
\hline
\end{tabular}

Note: Agricultural rainfall is rainfall measured over agricultural land during the growing season (see the data section in the main text for details). The left-hand-side variable in columns (1) and (5) is an indicator variable that takes the value of 1 if a country that is an autocracy at $\mathrm{t}-1$ is a democracy at $\mathrm{t}$ and the value of 0 otherwise. The left-hand-side variable in columns (2) and (6) is an indicator variable that takes the value of 1 if a country that is an autocracy at $t-1$ is a democracy at $t+2$ and the value of 0 otherwise. The lefthand-side variable in columns ( 3 ) and (7) is an indicator variable that takes the value of 1 if a country that is an autocracy at $t-1$ is a democracy at $t+4$ and the value of 0 otherwise. The left-hand-side variable in columns (4) and ( 8$)$ is an indicator variable that takes the value of 1 if a country that is an autocracy at $t-1$ is a democracy at $t+9$ and the value of 0 otherwise. The classification of democratic and autocratic regimes in columns (5)-(8) is based on Geddes, Wright, and Frantz (2014). The classification of democratic and autocratic regimes in columns (1)-(4) is based on Bjornskov and Rode (2017) who extend the dataset of Cheibub, Gandhi, and Vreeland (2010) and Przeworski, Alvarez, Cheibub, and Limongi (2000). The sample refers to countries with an average share of agricultural in GDP over the sample period in the top quintile of the distrbution. The countries included are those with an average share of agricultural in GDP over the sample period (1980-2013) in the top quintile of the distribution and with democratization data. The table reports robust standard errors clustered at the country level. * denotes significance at the $10 \%$ level; ${ }^{* *}$ significance at the $5 \%$ level; and ${ }^{* * *}$ significance at the $1 \%$ level. 


\section{APPENDIX TABLE 5. Rainfall Shocks and Polity Project/Freedom House Democratic Change since 1960: From Short to Longer Term}

\begin{tabular}{|c|c|c|c|c|c|c|c|c|}
\hline & \multicolumn{4}{|c|}{ Polity Project Polity Score } & \multicolumn{4}{|c|}{ Freedom House Political Rights Index } \\
\hline & \multicolumn{4}{|c|}{ Polity Score Change between $\mathrm{t}-1$ and } & \multicolumn{4}{|c|}{ Political Rights Index Change between $\mathrm{t}-1$ and } \\
\hline & $\begin{array}{l}\mathrm{t}(1- \\
\text { Year })\end{array}$ & $\begin{array}{l}\mathrm{t}+2(3- \\
\text { Year) }\end{array}$ & $\begin{array}{c}t+4(5- \\
\text { Year) }\end{array}$ & $\begin{array}{c}\text { t+9 (10- } \\
\text { Year) }\end{array}$ & $\begin{array}{l}\mathrm{t}(1- \\
\text { Year })\end{array}$ & $\begin{array}{l}t+2(3- \\
\text { Year) }\end{array}$ & $\begin{array}{c}\mathrm{t}+4(5- \\
\text { Year) }\end{array}$ & t+9 (10-Year) \\
\hline & $(1)$ & $(2)$ & $(3)$ & (4) & $(5)$ & $(6)$ & $(7)$ & (8) \\
\hline Rainfall $\mathrm{t}$ & $\begin{array}{l}-0.1968 \\
(0.1254)\end{array}$ & $\begin{array}{c}-0.6411 * * * \\
(0.2191)\end{array}$ & $\begin{array}{c}-0.5963^{* *} \\
(0.2372)\end{array}$ & $\begin{array}{c}-0.5931^{* *} \\
(0.2564)\end{array}$ & $\begin{array}{c}-0.0632 * * \\
(0.0301)\end{array}$ & $\begin{array}{c}-0.1423^{* *} \\
(0.0572)\end{array}$ & $\begin{array}{c}-0.2197 * * * \\
(0.0783)\end{array}$ & $\begin{array}{c}-0.2098^{* *} \\
(0.0895)\end{array}$ \\
\hline $\begin{array}{l}\text { Quadratic } \\
\text { Rainfall t }\end{array}$ & $\begin{array}{c}0.0040 \\
(0.0028)\end{array}$ & $\begin{array}{c}0.0141^{* * *} \\
(0.0050)\end{array}$ & $\begin{array}{l}0.0108^{*} \\
(0.0056)\end{array}$ & $\begin{array}{l}0.0121^{*} \\
(0.0063)\end{array}$ & $\begin{array}{c}0.0012^{* *} \\
(0.0006)\end{array}$ & $\begin{array}{c}0.0033^{* * *} \\
(0.0012)\end{array}$ & $\begin{array}{c}0.0041^{* *} \\
(0.0017)\end{array}$ & $\begin{array}{l}0.0035^{*} \\
(0.0021)\end{array}$ \\
\hline Rainfall t-1 & $\begin{array}{l}-0.1164 \\
(0.1082)\end{array}$ & $\begin{array}{c}-0.1938 \\
(0.1837)\end{array}$ & $\begin{array}{c}-0.2633 \\
(0.2025)\end{array}$ & $\begin{array}{l}-0.1596 \\
(0.2680)\end{array}$ & $\begin{array}{c}0.0156 \\
(0.0293)\end{array}$ & $\begin{array}{l}-0.0992 * \\
(0.0544)\end{array}$ & $\begin{array}{c}-0.1964 * * * \\
(0.0733)\end{array}$ & $\begin{array}{c}-0.1463 \\
(0.0969)\end{array}$ \\
\hline $\begin{array}{l}\text { Quadratic } \\
\text { Rainfall t-1 }\end{array}$ & $\begin{array}{c}0.0036 \\
(0.0028)\end{array}$ & $\begin{array}{c}0.0035 \\
(0.0042)\end{array}$ & $\begin{array}{c}0.0041 \\
(0.0047)\end{array}$ & $\begin{array}{c}0.0043 \\
(0.0063)\end{array}$ & $\begin{array}{c}0.0002 \\
(0.0006)\end{array}$ & $\begin{array}{l}0.0021 * \\
(0.0012)\end{array}$ & $\begin{array}{c}0.0034^{* *} \\
(0.0016)\end{array}$ & $\begin{array}{c}0.0029 \\
(0.0022)\end{array}$ \\
\hline Rainfall t-2 & $\begin{array}{c}-0.3517^{* *} \\
(0.1372)\end{array}$ & $\begin{array}{c}-0.4779 * * \\
(0.1978)\end{array}$ & $\begin{array}{c}-0.2995 \\
(0.2089)\end{array}$ & $\begin{array}{l}-0.1157 \\
(0.2631)\end{array}$ & $\begin{array}{c}-0.0961^{* * *} \\
(0.0366)\end{array}$ & $\begin{array}{c}-0.1865 * * * \\
(0.0591)\end{array}$ & $\begin{array}{l}-0.1362^{*} \\
(0.0725)\end{array}$ & $\begin{array}{l}-0.1668 * \\
(0.0982)\end{array}$ \\
\hline $\begin{array}{l}\text { Quadratic } \\
\text { Rainfall t-2 }\end{array}$ & $\begin{array}{c}0.0084^{* *} \\
(0.0034)\end{array}$ & $\begin{array}{c}0.0100^{* *} \\
(0.0046)\end{array}$ & $\begin{array}{c}0.0055 \\
(0.0048)\end{array}$ & $\begin{array}{c}0.0018 \\
(0.0060)\end{array}$ & $\begin{array}{c}0.0017^{* *} \\
(0.0008)\end{array}$ & $\begin{array}{c}0.0033^{* *} \\
(0.0013)\end{array}$ & $\begin{array}{c}0.0023 \\
(0.0016)\end{array}$ & $\begin{array}{c}0.0031 \\
(0.0021)\end{array}$ \\
\hline $\begin{array}{l}\text { Linear \& } \\
\text { Quadratic } \\
\text { Temperature in } \\
\text { Different Years }\end{array}$ & Y & $Y$ & $Y$ & Y & Y & Y & $Y$ & Y \\
\hline $\begin{array}{l}\text { Country Fixed } \\
\text { Effects }\end{array}$ & $\mathrm{Y}$ & Y & Y & Y & Y & Y & Y & Y \\
\hline $\begin{array}{l}\text { Year Fixed } \\
\text { Effects }\end{array}$ & Y & $Y$ & Y & $Y$ & $Y$ & Y & $Y$ & Y \\
\hline $\begin{array}{l}\text { Country Specific } \\
\text { Linear Time } \\
\text { Trends }\end{array}$ & Y & $Y$ & Y & Y & Y & $Y$ & Y & Y \\
\hline Countries & 30 & 30 & 30 & 30 & 30 & 30 & 30 & 30 \\
\hline Observations & 1,099 & 1,068 & 1,030 & 944 & 1,170 & 1,098 & 1,032 & 880 \\
\hline R Squared & 0.033 & 0.061 & 0.06 & 0.038 & 0.03 & 0.042 & 0.042 & 0.023 \\
\hline
\end{tabular}

Note: The left-hand-side variables in columns (1) to (4) are the changes in the Polity Project polity score in autocracies over different time periods. The left-hand-side variable in column (1) is the change in the polity score between years $t-1$ and $t$; the left-hand-side variable in column (2) is the change in the polity score between years $t-1$ and $t+2$; the left-hand-side variable in column (3) is the change in the polity score between years $t-1$ and $t+4$; and the left-hand-side variable in column (4) is the change in the polity score between years $t-1$ and $t+9$. The left-hand-side variables in columns (5) to (8) are the negative changes in the Freedom House political rights index over different time periods (I take the negative change to ensure that a higher Freedom House index indicates more political rights and thereby make results more comparable to those with the change in the polity score). The left-hand-side variable in column (5) is the change in the political rights index between years $\mathrm{t}-1$ and $\mathrm{t}$; the left-hand-side variable in column (6) is the change in the political rights index between years $t-1$ and $t+2$; the left-hand-side variable in column (7) is the change in the political rights index between years $t-1$ and $t+4$; and the left-hand-side variable in column (8) is the change in the political rights index between years $t-1$ and $t+9$. The countries included are those with an average share of agricultural in GDP over the sample period in the top quintile of the distribution (in Table 1 column (1)) and with Polity Project/Freedom House data. The table reports robust standard errors clustered at the country level. ${ }^{*}$ denotes significance at the $10 \%$ level; ${ }^{* *}$ significance at the $5 \%$ level; and ${ }^{* * *}$ significance at the $1 \%$ level. 